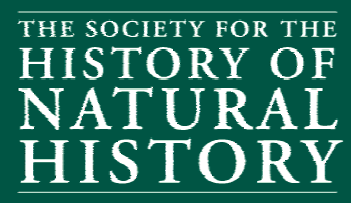

Copyright (C) The Society for the History of Natural History

registered charity no 210355

All Rights Reserved.

This file is provided for personal use only.

This publication may not be reproduced or transmitted, in any form or by any means, electronic, mechanical, photocopying, recording, scanning or otherwise, by a third party without the permission in writing of the author(s) and the Society for the History of Natural History

Requests for permission for other kinds of use, such as copying for general distribution or for creating new works, should be addressed to the Honorary Editor.

This paper is published in

ARCHIVES OF NATURAL HISTORY

The Society for the History of Natural History

c/o The Natural History Museum,

Cromwell Road,

London SW7 5BD,

United Kingdom.

Website - www.shnh.org

Editorial email address - editor@shnh.org 


\title{
Joan Salvador and James Petiver: a scientific correspondence (1706-1714) in time of war
}

\author{
JOSEP M. CAMARASA ${ }^{\mathrm{A}}$ and NEUS IBÁÑEZB \\ A Grup de Treball d'Història de la Ciència, Institut d'Estudis Catalans, Carme, 47, E-08001 Barcelona, Catalonia, \\ Spain (e-mail: jcamarasa@iec.cat). \\ B Institut Botànic de Barcelona, Passeig del Migdia s/n., E-08038 Barcelona, Catalonia, Spain (e-mail: nibanez@ibb. \\ csic.es).
}

\begin{abstract}
At the time of the war of the Spanish Succession (1705-1714), Joan Salvador and James Petiver, two apothecaries with an impassioned interest in understanding nature, began a long and fruitful correspondence that would only come to an end with Petiver's death. When this exchange of letters began, Salvador was a 20 -year old Catalan apothecary who had just spent two years travelling through France and Italy learning about botany and natural history with some of the best teachers at that time. Petiver, who was 20 years older, was a member of the Royal Society, director of the Chelsea Physic Garden and a well-known figure in London. This paper sets out and discusses the correspondence (which is quite exceptionally complete) between these two naturalists during the wartime period between the end of 1706 and the fall of Barcelona on 11 September 1714. Their letters reflect the obstacles they had to face as a result of war and how they overcame them, and they also explain the reciprocal role played by both correspondents in their respective collections and libraries.
\end{abstract}

KEY WORDS: Catalonia - collections - history of science - War of the Spanish Succession.

RESUM: En mig de la Guerra de Successió d'Espanya (1705-1714), Joan Salvador i James Petiver, dos apotecaris curiosos i apassionats pel coneixement de la natura inicien una llarga i fructífera correspondència, que perdurarà fins a la mort de Petiver. El primer, català, és encara, quan comença aquest "comerç", un jove de poc més de vint anys que acaba de passar dos anys viatjant per França i Itàlia i aprenent botànica i història natural amb alguns dels millors mestres del seu temps. El segon, anglès, és vint anys més vell i una personalitat ben coneguda a Londres, membre de la Royal Society i director del jardí dels apotecaris de Chelsea. L'article recull i comenta la correspondència (excepcionalment completa) intercanviada entre aquests dos naturalistes durant el període de guerra que va de finals del 1706 fins a la caiguda de Barcelona l'11 de Setembre de 1714, reflecteix els entrebancs que els imposa la situació bèl-lica i com els superen i explica el paper recíproc de cada un dels corresponsals en les respectives col-leccions i biblioteques.

KEY WORDS: Catalunya - col-leccions - història de la ciència - guerra de Successió d'Espanya.

\section{INTRODUCTION}

The War of the Spanish Succession (1701-1714), which was a major armed conflict between the main European powers as they vied for more than ten years over the languishing Spanish empire, was of great importance in the history of the territories belonging to the Crown of Aragon (Aragon, Balearic Islands, Catalonia and Valencia) that were on the side of Archduke Charles of Austria, in his struggle against Philip of Bourbon to become King of Spain. This was particularly so in the case of Catalonia, where Barcelona served as the capital for the Austrian pretender to the Spanish throne from 1705 to 1712 . When Charles finally relinquished his aspirations under the Treaty of Utrecht, the city continued to resist the French and Castilian forces in defence of its own freedom until its capitulation on 11 September 1714.

The first few years of the War of Succession, however paradoxical it may seem, were 
particularly flourishing, in cultural terms, for the city of Barcelona, which was all of a sudden converted into the cosmopolitan court of one of the potentially most powerful monarchs in Europe, where personalities from all the powers favourable to the cause of Archduke Charles were continually passing through. With regard to science, this period saw the beginning of circles that brought together not just interested locals but also many foreigners, as a result of the presence of the military and naval forces belonging to the various European powers that were garrisoned there, as well as people passing through the city, and ambassadors and entourages associated with the court. This also facilitated correspondence with those carrying out related work in the countries of origin of these foreign visitors.

One particularly significant case of this flourishing of science is the correspondence begun by Joan Salvador (1683-1726) after his return to Barcelona in the autumn of 1706 with various naturalists in different European countries, of which Hermann Boerhaave and James Petiver stand out, the correspondence with the latter being the most complete. Few of the letters and documents exchanged between Joan Salvador and James Petiver are in fact believed to have been lost . Most of Salvador's letters to Petiver are conserved in The British Library, among the Sloane Manuscripts, either in their original form or as copies or versions in Petiver's copybooks. Most of Petiver's letters and desiderata are conserved in the Salvador Library of the Institut Botànic de Barcelona, together with numerous books and other printed matter sent by him, and we know about some that have not been conserved because of Petiver's copybooks.

The volume and historical importance of this correspondence make it impossible to deal with all in just one paper, and for this reason we decided to subdivide them into significant stages. The first is the difficult stage covering the initial period of the relationship between both naturalists, from the first of Joan Salvador's letters up until Petiver's letter in which he joyfully announces that he has learnt of his correspondent's survival following the fall of Barcelona on 11 September 1714, contrary to what he had believed. An abridged sample of this correspondence appeared several years ago (Camarasa, 1989: 39-42). A complete transcription of the letters is given here (together with other documents) in the original language (French in the case of Joan Salvador's letters, English in the case of James Petiver, and Latin in an occasional letter or document enclosed with the correspondence), and they are set within their historical, social and scientific context, with an evaluation of the testimony offered by them in relation to the scientific activity of both correspondents and their respective networks of scientific correspondence. ${ }^{1}$

\section{THE START OF THE CORRESPONDENCE}

Joan Salvador i Riera (1683-1726) has probably been the most important figure in the Salvador family of Catalan apothecaries which, from the end of the sixteenth until the mid-nineteenth century, contributed distinguished personalities to the realm of natural history, in particular of botany, and helped to create both a fine library and some valuable natural history collections, the greater part of them conserved nowadays in the Institut Botanic de Barcelona. He lived through one of the most critical periods in Catalan and Spanish history and, although this circumstance stopped him from achieving a work of major scope, it nevertheless gave him the opportunity of forming relationships with a great variety of figures within the world of science, and also provided him with a complete scientific training. He studied in Montpellier (1704-1705), where he was a disciple of Pierre Magnol, as his father - Jaume Salvador i 
Pedrol - had been some time ago, and in Paris (1705-1706), where he was trained under Tournefort who accommodated him in his house as his son. Unfortunately, during his stay in Paris, the Succession War in Spain erupted, which implied that he was suddenly in an enemy country with the impossibility of returning to Barcelona. This circumstance forced him to go to Italy, where he met Michelangelo Tilli, teacher in Pisa, and Giovanni Battista Trionfetti, who taught in Rome. He came back to Barcelona in the autumn of 1706, with the plants that he had collected and the collections that he had built up during his journeys around France and Italy, and he started to establish fruitful correspondence with distinguished naturalists, such as James Petiver, Hans Sloane and Hermann Boerhaave. Once the war had finished, he resumed his relationships with the French scientific circles where he had received his training (Camarasa, 1995) and in 1715 he was designated as correspondent of the Parisian Academie Royale de Sciences, and in the following year he was invited to carry out, in company with Antoine de Jussieu who had been a fellow student of his in Paris, a scientific journey around Spain and Portugal that involved an itinerary of more than eight months around the Peninsula, with particular attention paid to Portugal (Salvador i Riera, 1972). He was the person who began the present arrangement of the collections of the family, which he enriched notably, particularly those of the herbarium, which was ordered according to the Tournefort system (Camarasa, 2004). Joan Salvador i Riera took the initiative to correspond with James Petiver in December 1706. He had returned to Barcelona a few months previously after having travelled for two years in France and Italy (Pourret, 1796; Pourret and Colmeiro, 1844; Bolòs, 1959; Camarasa, 1989) as it appears in his letter ${ }^{2}$, together with mention of the acquaintances that he made during his travels, including his teacher Tournefort, who he proclaims to be an "intimate friend". This letter of Joan Salvador undoubtedly served as the model for letters sent at the same time to other established naturalists who formed a network of exchange in which he was interested in becoming a part.

James Petiver (c.1663-1718) was a distinguished London apothecary and member of the Royal Society who had acquired considerable prestige as a naturalist (Allen, 2004). A disciple and friend of John Ray, he was in charge for many years of the Chelsea Physic Garden and during his life he assembled an important natural history collection that, on his death, was acquired, together with his manuscripts and library, by Hans Sloane for the price at that time of $£ 3,000$. The fact that Sloane's collections and library established the British Museum explains why Joan Salvador's letters to Petiver are now in The British Library. There are also many plants in Sloane's herbarium (Dandy, 1958) that had been sent by Joan Salvador; some of these had been sent directly to Sloane, but the majority of them originated from the exchanges between Salvador and Petiver (Ibáñez et alii, 2006).

Joan Salvador's first letter, written in French ${ }^{3}$, was dated on 24 December 1706 (NS).

It is now two months since my return from France and Italy, where I spent two years just learning about plants, and when I was in Montpellier I had the honour to speak with Mr Nisolle about your science in botany, and also with Mr Tournefort in Paris. I am an intimate friend of both and we have dealings with plants, and also with Mr Triumfetti and Mr Tilli. I would like, sir, to undertake the same with yourself and I offer you everything that is available to me and will inform you of everything concerning our beautiful plants in Catalonia, of which I am sending those that I have been able to collect since my return, although next year I will make sure to collect many others. I ask you, Sir, to be so kind as to send me a share of the plants and other curiosities that you receive from the Indies, such as shells, butterflies and others, the knowledge of which I am extremely enthusiastic about; if you wish for petrifactions, rock salt from Cardona, shells, marine plants and dried plants, in a word, anything to do with natural history, I will inform you of everything that we have in Catalonia; I ask you, Sir, to honour me with your orders. 
The context in which Joan Salvador took this initiative was this. When he returned to Barcelona he found the back room of his father's establishment converted into the headquarters of an informal academy where everybody who was interested in science in Barcelona, as well as those passing through the city, used to meet. This stimulating atmosphere, into which, in spite of his youth, he was accepted as one of the wiser members of the group (not in vain had he been a direct disciple of Tournefort and had the opportunity to collect and study plants with other French and Italian naturalists) now offered him a good platform for communicating with naturalists from the nations allied with Austria in support of Charles III's pretensions to the Spanish throne, at a time when direct communications with France were interrupted by the war.

Joan Salvador's letter reached Petiver three months later ${ }^{4}$ and was answered that same

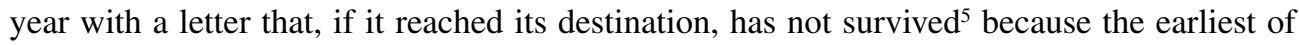
Petiver's letters conserved in the Salvador Library is dated one year after this and mentions a previous letter that was unanswered. Salvador's next letter makes no mention of any other letter from Petiver than the one transcribed below, dated 21 April 1708 (OS). ${ }^{6}$

Worthy $S^{\mathrm{r}}$

Altho I have not had an Answer to my last, yet I cannot miss this opportunity of writing to you by this Curious Gentleman \& my Worthy friend $\mathrm{D}^{\mathrm{r}}$ John Lecaan one of her Majesties of Great Britains Physicians, whom I recommend to your Acquaintance \& Freindship. By him you will receive a Collection of about 100 dry Plants $w^{\text {th }} 20$ English Ferns \& 30 Mosses, 40 East India Grasses, Cyperusses \& Rushes the Rest Cape Heath \& American officinales \&c $w^{\text {th }} 25$ English Buterflies \& some American. To these I have added the 10 Centuries of my Museum ${ }^{7}$ \& a Catalogue of t $^{\mathrm{e}}$ First Volumne of my Gazophylacium Naturae et Artis ${ }^{8}$ with 4 or 5 Tables of such Plants, Crusty Animalls, Shells \&c. as are to be met with in your parts \& which I should be glad to see.

I hope by $\mathrm{t}^{\mathrm{e}}$ first ship bound for London you will send me wever of these things you have duplicates of by you [illeg.] can gather in the interim. And I will return you as soon as I shall receive them a Curious collection of Indian Shells which I am putting up for you as also an other Book or two of dry Plants from Africa \& both $\mathrm{t}^{\mathrm{e}}$ Indies, with severall other things. What Plants you send me I desire you will (if not a nondescripts) put some one Authors Name to $\mathrm{t}^{\mathrm{m}}$ as Clusius, [Caspar Bauhin], [Johann Bauhin], Tournefort, \&c.

Pray as soon as this comes to your hands let me know of D. Nissoles Health \& if you hold a Correspondence with him I desire you will give my Respects to him \& send him a List of such Plants you cannot help me to, out of $\mathrm{t}^{\mathrm{e}}$ Catalogues of Magnol, \&c. And let him know I will by $\mathrm{t}^{\mathrm{e}}$ very next opportunity send him a collection of some things that endeavour to merit w'ever he sends me thro your hands.

I desire $S^{r}$. you will acquaint $D^{r}$ Tournefort when you write to him, that I was in expectation of receiving something from him by the hands of our Curious Freind $D^{r}$ Lavater a Swiss who was lately $w^{\text {th }}$ him $\&$ that if he pleases either thro your hands or any other safe conveniency as by way of Leghorn \&c. to send me what out of this vast stock he can easily spare I shall make him reciprocall returns \& I hope of such things he himselfe has not yet seen \& I beg of you $\mathrm{t}^{\mathrm{t}}$ you will tell him I desire to know his mind.

Doubt not $S^{r}$ but in your Travell thro Italy \& France amongst so many curious Naturalists \& Botanists you met with severall rare Plants \& other things, a Catalogue of which I should be glad to se [illeg.] samples of such you have duplicates, of I should be glad to know $\mathrm{w}^{t}$ amongst the Curious is publishing \& when we may expect to see $\mathrm{D}^{\mathrm{r}}$ Tournefort 2 volumes, which I hear are in the Press, \& I should be glad to have them.

$\mathrm{D}^{\mathrm{r}}$ Sloan, Secretary to our Royall Society hath lately Printed his first volumne of the Naturall History of Jamaica $\&$ c. Its a large Folio \& contains above 450 plates in large Tables \& is sold for 50 shillings.

This month is published $\mathrm{D}^{\mathrm{r}}$ Scheutzer his Itinera Alpina Tria ${ }^{9}$ a book very full of curious obserbables in botany \&c. a Coppy of which I present you with \& if either in Spain or elsewhere you can dispose of them att 10 shillings $t^{\mathrm{e}}$ Book I will send you what you desire which you may acquaint $\mathrm{y}^{\mathrm{r}}$ friends \& correspondence [illeg.] $\mathrm{t}^{\mathrm{e}}$ like I should be glad to serve you in concerning any new Bookes relating to Nature \&c.

$\mathrm{D}^{\mathrm{r}}$ Lecaan will give you directions how to send $\mathrm{y}^{\mathrm{r}}$ Letter ffrank to me, or will take Care of them himselfe. I therefore desire you will not fail to let me know immediately $\mathrm{y}^{\mathrm{r}}$ receipt of these things \& how you like them, but, if they are not so acceptible as you might expect, pray let me know wherein \& I will endeavour by te $^{\mathrm{e}}$ next to amend being very desirous to approve my selfe.

Worthy $\mathrm{S}^{\mathrm{r}}$ your most affectionate Freind \& humble Servant 


\author{
James Petiver \\ London Ap. 211708 \\ you may direct for me James Petiver Apothecary to $\mathrm{t}^{\mathrm{e}}$ Chartreaux \& Fellow of $\mathrm{t}^{\mathrm{e}}$ Royal Society in Aldergate \\ Street, London.
}

This letter and the consignment of specimens accompanying it reached Joan Salvador almost four months later, probably because the fleet in which Lecaan (Desmond, 1977; Martí-Escayol, 2001) was travelling did not go directly to Barcelona but visited various other ports beforehand. It was likely the Admiral Leake's fleet, which first went to Genoa to pick up the wife of the Habsburg king Charles III to take her to Catalonia (landing at Mataró on 23 July 1708 and entering Barcelona on 1 August) and then went on in September to occupy Minorca. Given these vicissitudes, it is not surprising that part of the consignment that arrived was more or less spoilt. Joan Salvador was not long in replying and the courier this time was a surgeon in the British army, Pelham Johnson, who was returning home. This letter ${ }^{10}$ must have also followed the variable route of a fleet that did not head directly to England because Petiver only received it, according to one of his annotations, on 5 January 1709 (OS), almost four months after it was written.

At the end of August I received from Mr Lecaan, the well known doctor from your nation, the plants
and butterflies, although slightly spoilt due to the humidity, Mr Scheuchzer's book, your Museum and the
Gazophylacium natura et artis without the tables (which I request that you send) and four more tables that
show different crustaceans and plants, almost all of which I will be able to send you. I enclose a box with the
plants that are in the catalogue, and one or two petrifactions and shells that can be found here in Catalonia.
I trust that in the future I will be able to send more things for your interest and I will be careful, on my
travels around Catalonia, to collect some things for you. I would be grateful if you could send me the drugs
that appear in the catalogue and some petrifactions from England, which Mr Lister has described, and also
continue to send me a share of the plants, butterflies and other things that you have in your museum, and I
trust that you will increase mine with very strange things. If you receive any rare drug, please send me some,
as I wish to greatly increase my drug collection. If you do me the honour to send me something but do not
find anybody trustworthy to bring it here, you can either send it to Mr George Crowe, consul of your nation
in Barcelona or to the wife of Mr Lecaan, who will find room for it among the packages to be sent to her
husband in this city. I enclose a bill of exchange for $£ 6$ sterling for the purchase of the books in the catalogue
and if this is not enough, do not desist from buying them, as I will repay you any extra money that you need
to spend. I have forwarded your compliments to Mr Nisolle and Mr Tournefort and trust that I am your most
affectionate and very humble and most faithful friend and servant. Barcelona 22 September 1708 . Dr. Joan
Salvador, apothecary, Barcelona.

At the top of the letter, there is a hand-written annotation by Salvador, as a kind of postscript, and several others possibly written either by an intermediary involved in the transportation or Petiver himself, all of which are quite difficult to read. The one by Salvador stated (in French): "If you know any new book of insects, [illeg.] or of natural history I ask you [illeg.]". The other annotations, as far as we have been able to make out, detail the characteristics of the box sent by Salvador (the box was marked "AR N 8 " in large letters; it weighed 21 pounds for which Petiver was paid five shillings and sixpence) and some of the mishaps that occurred during consignment.

On the back of this page there is a list of plants in Petiver's handwriting, possibly those sent by Salvador on this particular occasion.

The letter shows Salvador to be more self-confident and even somewhat pretentious, claiming he had been awarded a doctorate, which was untrue, and spending in a free-and-easy way that was only possible for very few people at that time. He also sought to please his correspondant by saying he had passed his compliments on to Nisolle and Tournefort, which would have been difficult to do from Barcelona unless he did so by way of Italian friends or 
colleagues, as a result of the difficulty during wartime of communicating with France.

Probably as a result of his being unsure about the consignment having been packed properly, Salvador wrote a second letter two months later as confirmation. ${ }^{11}$ It appears to have been received by Petiver on 11 February 1709 (OS), more than three months after it was sent.

I trust you will receive from either Mr Pelham Johnston, physician in St John's College, Cambridge, or from Mr William Neilson, ohysician at Mr James Neilson's surgery in Little Cisel Street, near Queen's Weighouse, London, a box containing plants and petrifactions and a bill of exchange for the purchase of the books I have marked in the catalogue, and also a catalogue of the drugs that I request, and please include the rarest that you have, in addition to plants and butterflies, etc. At the first opportunity that a ship leaves for London, I will send you shells and other things. I ask you to continue with our exchanges.

This letter reveals the identity of at least two medical practitioners that had come into contact with the Salvadors' group in Barcelona.

\section{THE LECAAN CONNECTION}

On 11 (22 NS) February 1709, Petiver also received a letter ${ }^{12}$ from John Lecaan, his friend and correspondent who had been the courier for his first consignment to Salvador (Desmond, 1977; Martí-Escayol, 2001). The letter is not dated but was probably written around the same time as the one from Salvador and entrusted to the same courier, given that both arrived together and the information that they contain overlaps and is complementary. Unfortunately the letter is torn and part of the text in the first paragraph is missing.

\section{$\mathrm{M}^{\mathrm{r}}$ Petiver}

$\mathrm{S}^{\mathrm{r}}$

I hope that by this time one $\mathbf{M}^{\mathrm{r}}$ Johnson hath delivered you what $\mathbf{M}^{\mathrm{r}}$ Salvador hath send you, [illeg.] which he doth expect your $\mathrm{k}$ [ind] return and is preparing $\mathrm{m}$ [ore th]ings to send you by the fi[rst op]portunity and I hope like him to send you few shels a friend of mine got in Port Mahon, I was in Tarragona where in the ruine of old churches and church yards several meddals are found, there is likewise several old roman inscriptions upon stones found buried under ground occasioned by digging to fortifie the said place, I wish I had a skill to know the value of all those, to send you or your friends a copie of them, if you send here any thing, you may put them amonghst the chest of medecines in the savoye, this is all att present

from $\mathrm{S}^{\mathrm{r}}$ your humble servant

J. Lecaan

These two letters must have crossed Petiver's following letter addressed to Lecaan, of which only a copy from one of Petiver's copybooks is available. ${ }^{13}$ Petiver's handwriting, which is always difficult to make out, is particularly careless in the copybooks and there are several gaps in the transcription although the document as a whole is clearly understandable.

$\mathrm{D}^{\mathrm{r}}$ Lecaan

Worthy Friend

Having not as yet heard either from $\mathrm{D}^{\mathrm{r}}$ Salvador or $\mathrm{y}^{\mathrm{r}}$ Selfe it makes [illeg.] I know whether he has received $\mathrm{t}^{\mathrm{h}}$ things I sent by you \& if so I was in hopes [illeg.] this to have had a Cargoe from him $w^{\text {ch }}$ if he has not already sent, pray as soon as this comes to $\mathrm{y}^{\mathrm{r}}$ hands press him very earnestly to it, \& let him know I have other Curiosities ready for him $\mathrm{w}^{\text {ch }} \mathrm{I}$ will send as soon as I receive any thing from him. I hope also you have made a Collection at Gibraltar $\mathrm{y}^{\mathrm{r}}$ selfe because I design a Catalogue to print an Acct of $\mathrm{t}^{\mathrm{h}}$ Plants Shells Insects \&c found at that town \& on Mount Calpe some of $\mathrm{w}^{\text {ch }} \mathrm{I}$ already have \& would willingly add others of $\mathrm{t}^{\mathrm{h}}$ collecting or procuring to them. I therefore pray $\mathrm{t}^{\mathrm{t}}$ both you $\& \mathrm{D}^{\mathrm{r}}$ Salvadore will oblige any persons you know there, or that shall go rather to make Collections for me. $\mathrm{T}^{\mathrm{e}}$ like if $\mathrm{y}^{\mathrm{u}}$ can att Sardinia \& Port Mahon Mallorca or any other Islands the Spaniards or [we] sail to. 
I hope you are not unmindfull of $\mathrm{y}^{\mathrm{r}}$ promise in Collecting me $\mathrm{w}^{\mathrm{t}}$ ever Plants, Shells or Insects you meet with in Spain \& that you will send me what you have already got by $\mathrm{t}^{\mathrm{h}}$ first ship that come for England, that I may $\mathrm{t}^{\mathrm{e}}$ sooner let you $\& \mathrm{t}^{\mathrm{e}}$ world see what those parts afford $\&$ who they are obliged to for them. I have since $\mathrm{y}^{\mathrm{u}}$ left England printed several little Tracts relating to these things $\mathrm{w}^{\mathrm{ch}}$ as soon as I receive any collection from you I will send as you shall give me directions. Pray accept of my hearty Respects with $\mathrm{t}^{\mathrm{h}}$ same to $\mathrm{D}^{\mathrm{r}}$ Salvador \& assure him $\mathrm{t}^{\mathrm{t}}$ you both are in $\mathrm{t}^{\mathrm{h}}$ list of our absent Friends every Saturday night whose healths are drinken \& that nothing will be more acceptible to me than learning suddenly from you both $\mathrm{w}^{\text {ch }}$ pray let him immediatly know from

Worthy $\mathrm{F}^{\mathrm{r}}$ Both his \& your most affectionate Friend \& humble Servant

J. P.

Octob. $3 \cdot 1708$

Lecaan sent a short letter from Barcelona dated 10 February $1709^{14}$, which appears to be the Flemish correspondent's laconic reply to Petiver's letter.

Barcelona febr. $10 \mathrm{t}^{\mathrm{h}} 1709$

$S^{r}$

Altho our continual bussiness doth not let us have any opportunity or time to Collect in this country as much as you expect, yet I have found att Tarragona in the very substance of the rocks blowed up to make the fortifications there, the shels, etc. of differente figure, that nature did fream ${ }^{15}$ so dexterously, of wich sorte perhaps you did never see before. $\mathrm{M}^{\mathrm{r}}$ Salvadore is likewise very diligent to send you what he can get in this countrey, which I hope will satisfie you better than what I can find, after my humble service, to all our friends with you I remain

$\mathrm{S}^{\mathrm{r}}$ Your most humble servant

John Lecaan

Petiver's most immediate response on receiving Salvador's consignment, together with his letter and the first one from Lecaan that he received simultaneously, was a letter addressed to Lecaan, dated 17 February 1709 (OS), which was less than a week after having received them. ${ }^{16}$ The content of the letter, the original of which we cannot trace, only exists in one of Petiver's copybooks and its transcription is difficult, as noted above.

\section{$\mathrm{D}^{\mathrm{r}}$ Lecaan}

Worthy $\mathrm{S}^{\mathrm{r}}$

$\mathrm{Y}^{\mathrm{r}} \mathrm{I}$ rec ${ }^{\mathrm{d}}$ on Friday last with one inclosed from $\mathrm{D}^{\mathrm{r}}$ Salvadore, both $\mathrm{w}^{\mathrm{ch}}$ were very acceptible but above all his Collection of Spanish plants $w^{\text {ch }} I$ received $t^{\mathrm{e}}$ week before, I could have wish ${ }^{\mathrm{d}}$ there had been more of these, for I find many amongst $\mathrm{D}^{\mathrm{r}}$ Johnston's own Collections, $\mathrm{w}^{\mathrm{ch}}$ are not amongst these he sent me, however pray let him know I am putting up more for him $w^{\text {ch }}$ I will suddenly send him with the bookes he wish for, as also severall things he desires in his Catalogues of Drugs. I desire he will forthwith send this Catalogue of Mompelier Plants to $D^{r}$ Nissole \& $t^{t}$ he will write him [illeg.] he shall not fail of a collection of my Curious Indian Plants for such he shall send me mentioned in $\mathrm{t}^{\mathrm{t}}$ List amongst these send to $\mathrm{D}^{\mathrm{r}}$ Salvadore.

You may be assured Worthy $\mathrm{S}^{\mathrm{r}}$ your Port Mahon shells will be very acceptible as also wherer Plants you can procure from those Islands as Sardinia $\& \mathrm{c} \mathrm{w}^{\mathrm{ch}} \mathrm{I}$ beg you will use your utmost interest to got for me \& with those $\mathrm{D}^{\mathrm{r}}$ Salvadore sends next time $\mathrm{w}^{\text {ch }} \mathrm{I}$ hope for by $\mathrm{t}^{\mathrm{e}}$ first Opportunity. I expect $\mathrm{y}^{\mathrm{u}}$ will favour me with a Collection of Spanish plants of $y^{r}$ own particular procuring $\mathrm{w}^{\mathrm{ch}}$ may serve for materials to enlarge $\mathrm{t}^{\mathrm{e}}$ next edition of $\mathrm{y}^{\mathrm{r}}$ so acceptible Treatise I desire you will once or twice at least every Month employ a Man purposely to fill Bookes with wherer Plants they shall meet with without any distinction of being rare or comon, since both from those parts will be acceptible for me.

As for medals, if $\mathrm{y}^{\mathrm{u}}$ can purchase $\mathrm{t}^{\mathrm{m}}$ for little more than their intrinsick value $\mathrm{y}^{\mathrm{u}}$ [need] no doubt but you may at $\mathrm{y}^{\mathrm{r}}$ return make double $\mathrm{y}^{\mathrm{r}}$ money of them here besides obliging several Curious Men to be $\mathrm{y}^{\mathrm{r}}$ friends.

I hope $S^{r}$ neither $\mathrm{D}^{\mathrm{r}}$ Salvadore nor $\mathrm{y}^{\mathrm{u}}$ will omit any opportunity this spring \& ensuing sumer to get wherer plants $\mathrm{y}^{\mathrm{u}}$ meet with, \& pray assure him my respects \& [illeg.] to $\mathrm{y}^{\mathrm{u}}$ both. [illeg.] nothing can be more welcome to me than Collections of Nature \& pray let him know I will write particularly to him with the things I send \& $\mathrm{t}^{\mathrm{t}}$ it shall be my daily endeavour to approve my selfe.

Worthy Sr both his \& $\mathrm{y}^{\mathrm{r}}$ most affectionate Friend and humble Serv ${ }^{\mathrm{t}}$

London Febr. 17. 1709 
This letter is followed in the copybook by one addressed to Lecaan's wife, who must have been the intermediary for the consignment. ${ }^{17}$ This does not contribute anything of importance concerning the subject at hand.

Communications did not improve during the following months. The route to Barcelona for the British now passed through Mahon, hence it was Archibald Stewart, appointed as Surgeon-General in Mahon, who was responsible for taking the consignments meant for Lecaan and Salvador. The absence of news from his correspondents and possibly an opportunity to send a message by trustworthy hands led Petiver to write another letter to Lecaan on 29 September $1709(\mathrm{OS})^{18}$, knowledge of which we only have (as in the case of the previous ones) from the transcript in Petiver's copybook.

Dr Lecaan

Worthy Sr, I am not a little Concerned $t^{t}$ the box I designed for Dr Salvadore with $y^{r}$ things by Dr Stewart were left behind, nevertheless I hope he will now suddenly receive $\mathrm{t}^{\mathrm{m}}$, pray assure him I have another Collection of very Curious Plants, Shells \&c ready for him, $w^{\text {ch }}$ I will send with the things Madam Lecaan is getting ready for $\mathrm{y}^{\mathrm{u}}$. Yr Lady yesterday shew me a Letter from you wherein $\mathrm{y}^{\mathrm{u}}$ say that Dr Salvadore \& $\mathrm{y}^{\mathrm{r}}$ selfe has gott some Collections ready for me. I hope they are already on their way for England. I beg $\mathrm{y}^{\mathrm{u}}$ will send $\mathrm{t}^{\mathrm{m}}$ by the first ships bound for London, with a Letter or advice separate. You mention some Shells from Port Mahon you have for me $\mathrm{w}^{\text {ch }}$ I long to [illeg.]. I hope Dr Salvadore has procured some Collections of Plants from that Island ${ }^{19}$ with their fruit \& seed. The [illeg.] I beg he will do of all $t^{\mathrm{e}}$ Plants $\mathrm{w}^{\mathrm{ch}}$ grow $\mathrm{b}^{\mathrm{t}}$ Barcelona, this being a proper [station] before $t^{t}$ winter approaches, for gathering ripe fruit \& seed to [raise] in our Physical Garden at Chelsey $\mathrm{w}^{\mathrm{ch}}$ is in part now under my Care. I hope now $\mathrm{y}^{\mathrm{u}}$ [illeg.] in $\mathrm{y}^{\mathrm{r}}$ Country ${ }^{20}$ you will not be unmindful of furnishing me with some Matter for improving \& [illeg.] the Materia Medica \& Practica of Physica [illeg.] in order to do $2^{\text {nd }}$ Edition of your last Treatise, $w^{\text {ch }} t^{\mathrm{e}}$ world will now begin to want, \& Clusius his history will be not small help to $\mathrm{y}^{\mathrm{u}}$. Pray forgett not to oblige one of $\mathrm{y}^{\mathrm{r}}$ servants or some other [Body] once a week at least to take a Brown Paper Book with $y^{\mathrm{u}}$ into the Fields $\mathrm{w}^{\text {ch }}$ let $\mathrm{t}^{\mathrm{m}}$ fill $\mathrm{w}^{\text {th }} 2$ or 3 sprigs of every sort of [illeg.] Tree Bush or Herb $\mathrm{y}^{\mathrm{u}}$ meet with, $\mathrm{w}^{\mathrm{ch}}$ I shall take as $\mathrm{y}^{\mathrm{r}}$ own Collections \& I hope by $\mathrm{y}^{\mathrm{r}}$ first [illeg.] I shall see what you [have] procured. For I am very ambitious of having $\mathrm{y}^{\mathrm{u}}$ with $\mathrm{D}^{\mathrm{r}}$ Salvadore [illeg.] print in relation to such Plants as grow in $\mathrm{y}^{\mathrm{r}}$ parts of Spain $\mathrm{w}^{\text {ch }} \mathrm{I}$ hope to receive from $\mathrm{y}^{\mathrm{u}} \& \mathrm{him}, \mathrm{w}^{\text {ch }} \mathrm{I}$ will publish \& send $\mathrm{y}^{\mathrm{u}}$ Coppies of $\mathrm{t}^{\mathrm{m}}$. Pray give me hearty Respects to $\mathrm{D}^{\mathrm{r}}$ Salvadore with $\mathrm{t}^{\mathrm{e}}$ same to $\mathrm{y}^{\mathrm{r}}$ selfe $\&$ be assured nothing can be more acceptible to me than hearing often \& effectively from you $\mathrm{w}^{\text {ch }}$ shall be retalliated by

Worthy $S^{r} Y^{r}$ most affectionate friend and humble servant

J. P.

Although the text is somewhat vague, it seems that Petiver's consignment to Joan Salvador, which should have arrived with Archibald Stewart, who was going to Mahon to take up the post of Surgeon-General, had been left behind. It is possible that Stewart did not even go to Barcelona and that the ship that he was on went directly to Mahon, which was a much safer destination for any British ship in the Western Mediterranean at that time. This would justify Petiver's expectation that the consignment would not take long in arriving. Lecaan apparently had to return to England via the Low Countries and for this reason Petiver made various orders through him and gave him some bibliographical recommendations. Towards the end of the letter he seems to refer to his intention of publishing some prints showing the most interesting plants in the consignments sent by Lecaan and Salvador.

Nevertheless, the only direct news received by Salvador from James Petiver, before the beginning of January 1710, was the consignment that he received when Lecaan arrived in Barcelona in August 1708. Reading the previous letter must have encouraged Joan Salvador to write again to his English correspondent, which he did on 16 January $1710 .{ }^{21}$

I learn from the letter that you wrote to Doctor Lecaan that you have made a good collection of plants and other things for me. I am very grateful to you and I request you send them at the first opportunity with part of the drugs in the Catalogue, and also the books I asked for last year. I also ask you, if you find Parkinson's 
botanical works ${ }^{22}$, Sibbald's Scotia illustrata ${ }^{23}$, Gerard's Historia plantarum emaculata ${ }^{24}$ and any other new book on natural history, to send me them and to indicate the price so I can reimburse you the money afterwards. If you receive anything, whether it be insects, fish, shells, petrifactions, minerals, butterflies, drugs, etc. I ask that you send me a share for I hope you will greatly add to my cabinet of curiosities.

A fleet is leaving for London a few days from now, in which I will send a box with the plants listed in the catalogue and a good congealment of Cardona rock salt; I do not have too many seeds but I will send you what I have, I ask you to send me a share of whatever you have. When I have another opportunity I will write more on this.

This letter was followed a few days later by a letter of confirmation, written this time in Latin, for reasons which we are unable to fathom, in which Joan Salvador clarifies matters regarding the progress of the consignment that he had proposed in his previous letter and that he was about to send..$^{25}$

I believe that two other letters of mine should have arrived in your hands, a catalogue of plants that I have collected this year and another catalogue of several items greatly desired by me for the enrichment of my Museum. Now I send you, in the frigate Hattley, commanded by Captain Thomas Young, the plants contained in the catalogue, some congealed salt from Cardona and other things; this year I will continue drying plants and I will send them by any appropriate means.

If you receive anything rare, whether it be shells, animals, plants or other natural things, please send me a share for I hope you will greatly increase my museum. I am also very interested in the Philosophical Transactions, of which I would like to have the whole collection up to the present, and then to receive the forthcoming issues; without forgetting the books which I have already asked you for in other letters, which I await as soon as you have occasion to send them.

Contrary to Joan Salvador's hopes, by February 1710 Petiver had still not received his consignments although they may have already arrived in England, as is apparent from Petiver's letter of 10 February 1709 (OS, 21 February 1710 NS) to John Lecaan, the copy of which is in one of Petiver's copybooks ${ }^{26}$ :

$\mathrm{D}^{\mathrm{r}}$ Lecaan

Whorthy $\mathrm{S}^{\mathrm{r}}$. I was last Night to wait on $\mathrm{y}^{\mathrm{r}}$ Lady who acquainted me with a letter she has this weeke rec ${ }^{\mathrm{d}}$ from you, in $w^{\text {ch }}$ she tells me you mention some Collections Dr Salvadore has sent me. I could have wished to have known by what ship, because here hath been severall come safe to London very lately, amongst them I hope my Collections are, but for want of advice by which, I am at a loss where to enquire. Pray therefore $\mathrm{S}^{\mathrm{r}}$ let him immediately send me word by $\mathrm{w}^{\mathrm{t}}$ Ship \& to whose Care he has committed them for untill I hear I shall be very much affraid of their miscarrying. You may $S^{r}$ assure him as soon as they come to my hands I will by the same ship send him another Considerable Collection with some tracts of Naturall History $\mathrm{w}^{\mathrm{ch}} \mathrm{I}$ have lately publish ${ }^{\mathrm{d}}$, these are to oblige him to make me quicker returns $\mathrm{t}^{\mathrm{gh}} \mathrm{I}$ must Confess I cannot in Equity expect it till he has received $\mathrm{t}^{\mathrm{e}} 2$ last Collections with the greatest part of the bookes he wrote for $\mathrm{w}^{\mathrm{ch}}$ have lain so long at Portsmouth, but they will now as Mad. Lecaan tells me very suddenly sent, $w^{\text {ch }}$ I beg you will acquaint him with \& that he will be pledged to let me know whether $\mathrm{D}^{\mathrm{r}}$ Magnol \& $\mathrm{D}^{\mathrm{r}}$ Nissole at Mompelier be living \& when heard from $\mathrm{t}^{\mathrm{e}}$ last.

$\mathrm{S}^{\mathrm{r}}$ I heartily congratulate you on $\mathrm{y}^{\mathrm{r}}$ daily great Acquisitions both in Honour \& Proffitt, hopping neither of $\mathrm{t}^{\mathrm{m}}$ will be obstacles to $\mathrm{y}^{\mathrm{r}}$ employing now $\&$ then amongst $\mathrm{t}^{\mathrm{e}}$ many servants at Comand one of $\mathrm{t}^{\mathrm{e}}$ most meniall to go once a week or oftner with a $\mathrm{R}^{\mathrm{m} 27}$ or two of Brown Paper (into the Fields, Woods, Mountains \&c) $\mathrm{w}^{\mathrm{ch}}$ let him fill with 2 or 3 Sprigs of all Sort of wh ${ }^{\text {ever }}$ Tree Bush or Herb he shall meet with without any distinction [\&] the new or $\mathrm{t}^{\mathrm{e}}$ Common, only writing in $\mathrm{t}^{\mathrm{e}}$ beginning of the Book on a peice of paper in $\mathrm{w}^{\mathrm{ch}}$ month $\&$ place $\mathrm{t}^{\mathrm{y}}$ where gathered, these [so] send I shall looke upon as your proper collections, \& shall distinguish $\mathrm{t}^{\mathrm{m}}$ as such from $\mathrm{D}^{\mathrm{r}}$ Salvadores when I come to print an $\mathrm{Acc}^{\mathrm{t}}$ of them as I hope to doe this Spring if yours come not too late. I hope $\mathrm{y}^{\mathrm{u}}$ will not also be unmindfull of all opportunities $\mathrm{t}^{\mathrm{t}}$ may offer $\mathrm{t}^{\mathrm{e}}$ engage such Persons you can, as goe to $t^{\mathrm{e}}$ Barbary coasts or any other in $\mathrm{t}^{\mathrm{e}}$ Mediterranean either continent or Island to gather what Plants, Shells or Insects $\mathrm{t}^{\mathrm{y}}$ may meet with, this $\mathrm{S}^{\mathrm{r}}$ will be an eternall obligation $\mathrm{w}^{\mathrm{ch}}$ I shall on all occasions acknowledge to $\mathrm{y}^{\mathrm{u}}$ utmost of my Power who am

$\mathrm{S}^{\mathrm{r}}$. $\mathrm{Y}^{\mathrm{r}}$ most affectionate friend \& Hearty [well]ed Wisher. J. P.

London Febr. 10.1709/10 
Petiver's second consignment finally reached Barcelona in April, according to a short note $^{28}$ that Lecaan sent to his correspondent in London:

Tarragona, april t $\mathrm{t}^{\mathrm{e}} 20$

$\mathrm{S}^{\mathrm{r}}$

I have received the book you have sent me, and the plants for $\mathrm{M}^{\mathrm{r}}$ Salvadore and I send you a little tree found here under [illeg.] up by the fisshermen of this place if it come safe to you, it is very curious; I hope that you have received all the plants and other things $\mathrm{M}^{\mathrm{r}}$ Salvadore has sent to you by the last fleet; as for my part it is impossible that my biseness [illeg.] let me make any collection therefore you be pleas to excuse me att present it is all att now from

$\mathrm{S}^{\mathrm{r}}$ Your most humble serv ${ }^{\mathrm{t}}$

John Lecaan

It appears that Petiver received this letter on 7 June 1710 from an annotation written by him on the letter itself. The next document in this correspondence is a long letter from the English apothecary addressed to Salvador, of which there are two versions, the original letter conserved in the Salvador collections in Barcelona ${ }^{29}$, and a copy in one of Petiver's copybooks..$^{30}$ The differences are minimal and are practically limited, in terms of the main body of the letter, to variations in the abbreviations used ${ }^{31}$, the list of plants referred to in the second paragraph, and a postscript. The list (not transcribed here), which is not in the copybook, is very long and arranged according to Magnol's Botanicum monspeliense (1676, 1686). The fact that it was ordered this way was of great help in interpretation and at the same time led to us finding a short description of a plant unnamed before (Lychnis minima hispida nodiflora Salvador) by Jaume Salvador ${ }^{32}$ and published in Magnol's appendix (Camarasa, 2000). The postscript bears a date that is one week after the date in the letter, which must have been the time that Petiver took to select plants from Botanicum monspeliense and to write the list.

Worthy $\mathrm{S}^{\mathrm{r}}$

$\mathrm{Y}^{\mathrm{r}}$ very acceptible Collection of dry Plants are at last come safe to hand, for $\mathrm{w}^{\mathrm{ch}}$ I return $\mathrm{y}^{\mathrm{u}}$ my hearty thanks hoping you have rec ${ }^{\mathrm{d}}$ ere $^{\mathrm{e}}$ Bookes \& Collections $\mathrm{w}^{\mathrm{ch}}$ lay so long at Portsmouth with others I have sent you since amongst $\mathrm{t}^{\mathrm{e}}$ medecines to $\mathrm{D}^{\mathrm{r}}$ Lecaan from Collonell Gower, which I hope will give $\mathrm{y}^{\mathrm{u}}$ great satisfaction $\&$ make $\mathrm{y}^{\mathrm{u}}$ a retalliation for those I have rec ${ }^{\mathrm{d}}$. I am making other Collections for $\mathrm{y}^{\mathrm{u}} \mathrm{w}^{\mathrm{ch}}$ I will send by $\mathrm{t}^{\mathrm{e}}$ first opportunity.

I formerly desired to know if $\mathrm{D}^{\mathrm{r}}$ Nissole [be] alive \& at Montpelier, $\mathrm{w}^{\text {ch }}$ pray inform me of by the next, in $\mathrm{t}^{\mathrm{e}}$ interim I have sent you a Catalogue of such Plants whose specimens or seeds will be very acceptible to me taken from $\underline{D}^{\mathrm{r}}$ Magnolle Botanicum Monspeliense what of these you have not growing $\mathrm{w}^{\mathrm{th}} \mathrm{y}^{\mathrm{u}}$, I desire $\mathrm{y}^{\mathrm{u}}$ will write to Montpelier for. I hope $\mathrm{y}^{\mathrm{u}}$ have a botanick correspondence at Port Mahon to procure $\mathrm{w}^{\mathrm{t}}$ plants grow in $\mathrm{t}^{\mathrm{t}} \& \mathrm{t}^{\mathrm{e}}$ neighbouring Isles ${ }^{33}$ as Corsica Sardinia \&c but particularly \& above all I should to be glad to see $\mathrm{t}^{\mathrm{t}}$. The Surgeon Generall att Port Mahone $\mathrm{M}^{\mathrm{r}}$ Archibald Stewart is a very Curious Person \& expert Botanist who promised to send me such Plants, \&c he should meet with in those parts but he hath not get been so good as his promise, as $\mathrm{y}^{\mathrm{u}}$ have frequent opportunities of sending thither I should be glad $\mathrm{y}^{\mathrm{u}}$ would hold a correspondence $\mathrm{w}^{\text {th }}$ him \& write to him $\mathrm{t}^{\mathrm{t}} \mathrm{y}^{\mathrm{u}}$ will take Care to convey to me $\mathrm{w}^{\mathrm{t} e v e r}$ he shall commit to $\mathrm{y}^{\mathrm{r}}$ Charge $\&$ in requitall I will return him $w^{t} e v e r$ he shall desire.

Rondeletius $\mathrm{t}^{\mathrm{t}}$ learned Phisitian \& consummate Naturalist hath wrote of severall fishes \& other Sea Animalls as are strangers to our Sea \& coasts as Canevi Squillae Mantes \& variae aliiae crustacei nec non Echini, Stellae marinae \& Cochleae perplures generes. I hope by $\mathrm{t}^{\mathrm{e}}$ next you will make me Colections of such of these as $\mathrm{y}^{\mathrm{r}}$ shoares afford with the Coralls, Corallines, Musci, Fuci, Spongiae, \&c These $\mathrm{w}^{\mathrm{th}} \mathrm{t}^{\mathrm{e}}$ Animalls may be sent stratum super stratum in any old Tub or Barrell than which nothing can be more acceptible to me.

I desire $\mathrm{y}^{\mathrm{u}}$ will send me a Catalogue of $\mathrm{t}^{\mathrm{e}}$ Herballs \& other Books \& Tracts in Naturall History $\mathrm{t}^{\mathrm{t}}$ I have already sent $\mathrm{y}^{\mathrm{u}} \&$ those $\mathrm{y}^{\mathrm{u}}$ want, having mislaid $\mathrm{t}^{\mathrm{e}}$ list of those $\mathrm{y}^{\mathrm{u}}$ wrote for. So $\mathrm{t}^{\mathrm{t}} \mathrm{I}$ know not certainly $\mathrm{w}^{\mathrm{t}} \mathrm{y}^{\mathrm{u}}$ have or still want.

I hope $\mathrm{y}^{\mathrm{u}}$ have this summer \& will continue to procure \& save me ripe seed of all $\mathrm{t}^{\mathrm{e}}$ more rare plants $\mathrm{y}^{\mathrm{u}}$ shall meet with about you or elsewhere $t^{\mathrm{e}}$ like $\mathrm{I}$ have done for you of such as come to perfection in our Company 
of Apothecaryes Phisick Garden of $w^{\text {ch }}$ I am a Director \& therefore must beg $y^{u}$ will not fail to supply us by every opportunity. These will take up but little room \& may therefore easily be sent by any friend $\mathrm{t}^{\mathrm{t}}$ comes to England over land.

As in my last I sent $\mathrm{y}^{\mathrm{u}}$ a Collection of our English beetles so I am now putting $\mathrm{y}^{\mathrm{u}}$ up another of Papiliones ${ }^{34}$ $\&$ Phalenae, I know $y^{u}$ have very beautiful ones of both these \& Scarabei $w^{\text {ch }}$ I hope $y^{u}$ will remitt me $w^{\text {th }}$ your next Collections.

I thank $\mathrm{y}^{\mathrm{u}}$ for $\mathrm{t}^{\mathrm{e}}$ few fossills \& Rock Salt $\mathrm{y}^{\mathrm{u}}$ sent, I should be glad to see more of them \& $\mathrm{t}^{\mathrm{e}}$ mineralls or oares $\mathrm{y}^{\mathrm{r}}$ Mines \& Quarries afford, I am putting our English ones in order, of $\mathrm{w}^{\mathrm{ch}} \mathrm{y}^{\mathrm{u}}$ shall suddenly have a share with divers of $\mathrm{t}^{\mathrm{e}}$ officinalls $\mathrm{y}^{\mathrm{u}}$ menction in $\mathrm{y}^{\mathrm{r}}$ Catalogue sent to

Worthy $\mathrm{S}^{\mathrm{r}} \mathrm{y}^{\mathrm{r}}$ most affectionate \& ready friend to serve you

James Petiver

Aldergate Street. London

Augt: 291710

P. S. I beg $\mathrm{S}^{\mathrm{r}}$ you will this Autum procure what bulbs your parts afford both wild and Garden, $\mathrm{t}^{\mathrm{t}} \mathrm{I}$ may have $\mathrm{t}^{\mathrm{m}}$ before $\mathrm{t}^{\mathrm{e}}$ spring for our Phisick Garden, with what seeds \& Plants you have gathered this summer $\mathrm{w}^{\mathrm{ch}} \mathrm{I}$ beg by $\mathrm{t}^{\mathrm{e}}$ first opportunity. Pray give me hearthy respects \& service to $D^{\mathrm{r}}$ Lecaan \& be pleased to accept of the same from, Worthy $\mathrm{S}^{\mathrm{r}}, \mathrm{y}^{\mathrm{r}}$ most affectionate \& humble servt. James Petiver. London. Septemb. 5. 1710

Petiver's letter and list did not arrive in Barcelona until November 1710. The war continued to make communications difficult despite the fact that the British navy had total control over all sea routes. As a result, Salvador's reply took two months longer and it was not until February 1711 that his new consignment for Petiver left Barcelona with John Lecaan, who was returning to England not by sea but overland. Unable to overload his luggage, Salvador could thus only entrust him with a folder containing a few plants, and he had to wait longer before he could send Petiver a bulkier consignment, which included an insect collection that he said he had already prepared, by sea. With the folder, Salvador also sent a longer letter ${ }^{35}$ dated 12 February 1711, in which, amongst other things, he gives an account of his intention to visit Majorca and Minorca:

Last December I had the honour to receive yours, in which I learned you had received the plants, stones, \&c that I had sent you. Now, on the occasion of our friend Dr. Lecaan, I send you a folder with several plants, as I cannot entrust him with more because of his overland journey, but at the first seaborne opportunity that occurs I will send you a box with different insects that I am keeping for you (as the aforementioned Dr. Lecaan will tell you) that are very well conserved. I also see from your letter a Catalogue of plants from which you would like some specimens and seeds to plant in the Garden, I expect to collect them for you in springtime, although we are very unfortunate in this country because of the enemies who limit us so much that we can only travel to part of Catalonia. Next April I trust I can get to Minorca and Majorca to botanise well the countryside there and to make a good collection of shells and plants and I will then be able to send you a share of some very nice things, and I am also expecting a good collection from an apothecary friend who lives in Mahon, according to what he has said in his latest letters. He worked in our shop for seven years. The books that you say were shipped some time ago with a fleet have still not arrived although the fleet is expected at any time. As you have specified neither the books nor the price, I have not been able to confirm whether to hand over much money but when I am informed I intend to have it sent to you. I have also sent you different lists of books and, if you send me ones other than those that I request here, I ask you to send me them, together with any other that comes out, and to address them for the present to Messrs Shallet and Crowe, English consuls in Barcelona, so that they can have them sent to me; this way they will arrive more safely and then, if you send me the bill, I will have the money delivered to you. I also enclose a catalogue of different things similar to that which I have already sent you, if you can send me them I would be very grateful. You could send them in envelopes with each one marked with the name. If you have any other unmentioned ones, please send me a share, and I trust, as I have already said, that you will greatly increase my Museum. I will endeavour to collect different species of crustaceans, seaweed, corallines, etc. that you ask for, even though our sea is very unfruitful I will send you them all together and you select them. Both the terrestrial and aquatic shells that you have, I would be very grateful, whether they are from England or anywhere else, if you could send me some, it is an aspect that I am very pleased with. If you know of any good book on flying, aquatic, and quadruped animals, etc., you could also send me them because I only have books by Aldrovandi ${ }^{36}, \mathrm{Jonston}^{37}$, Buonanni $^{38}$, and Langius' De lapidibus figuratis Helvetiae ${ }^{39}$. It is some time since I have heard from our 
friends in Montpelier, I trust they are in good health; the other day, an English surgeon coming from Genoa told me that they had told him that Mr Tournefort had died but as I have had no further news I do not believe it to be true. If you have shoots of Caryophyllus aromaticus (clove), Mirabolani (cherry plum), Cinnamomum (cinnamon) and others, please send me a share.

According to an annotation by Petiver, he received this letter on 31 May 1711 (OS) or, in other words, four months after the consignment. We were not able to find the enclosed lists, as implied by certain passages in the letter.

As one can see, this letter is rich in direct and indirect information. On the one hand, it mentions the difficult situation regarding the position of Charles' allied forces, and in particular the Catalans. Catalonia, which had still not been occupied by the French and Castilian forces, was relatively small so if Joan Salvador wanted to gather plants he had almost no alternative than to go to the islands of Majorca and Minorca. He had still not received any news from his French friends and moreover he chose not to believe the news that did reach him indirectly concerning Tournefort's death (which had occurred on 28 November 1708). ${ }^{40}$

The bearer of this letter was Lecaan who, for reasons that cannot be determined, did not travel directly to London. As he could not cross French territory, this meant he would have had to leave Barcelona by sea and travel to Genoa or Leghorn and from there, via Piemont and Savoy (domains of the Duke of Savoy), through Switzerland and along the Rhine valley, where there were numerous imperial territories, to the Low Countries, where he could get a boat to England. At that time, this excluded any possibility of excess luggage as the roads were difficult, in particular because the means of transport were of modest size and horsedrawn. This is why Salvador only entrusted Lecaan with a folder containing a few plants to give to Petiver, promising him further consignments that were partially ready when the occasion arose for them to be sent by sea. He also needed to make a spring and summer expedition to collect some of the plants in the list, based on Botanicum monspeliense, sent by Petiver the previous September, together with seeds, which would moreover greatly enhance his consignment with native plants from Majorca and Minorca. Salvador, on the other hand, already had indirect knowledge of the islands, at least of Minorca, as a result of a Minorcan apothecary apprentice who worked at his father's shop.

There were difficulties in communications in both directions and, if Joan Salvador was late in replying to a letter, with his replies taking months to reach their beneficiary, the delay in Petiver's consignments reaching him was even longer because Salvador had still not received part of a consignment sent at the end of 1708 when he wrote the letter just quoted $^{41}$, and it was for this reason that he recommended that subsequent ones be addressed to Shallet and Crowe, the English consuls in Barcelona.

It is also worth remarking on the clarifications in the letter in relation to the content of Salvador's library, which reveal the scope of Joan Salvador's interests as a naturalist. No mention is made, for example, of any book on botany, a subject in which he must have considered himself well provided with; nevertheless, despite having most of Aldrovandi's books, he considered that the ones he had on animals and rocks were insufficient.

\section{TRAVEL TO MAJORCA AND MINORCA}

The next letter, dated 30 July 1711 from Mahon ${ }^{42}$, is in some measure a continuation of this one as it confirms Salvador had undertaken his planned expedition to Majorca and Minorca, and in the meantime there had been no initiative on the part of Petiver, as far as 
we are aware.

These ships give me the opportunity to inform you herewith of certain plants that I found on that island and in particular Myrto Cistus Pennaei Clus., which really is an Ascyron that nevertheless is rare in Minorca, I found it in abundance in Majorca and I have named it Ascyrum Balearicum frutescens, magno flore foliis minoribus, lucidis subsus verrucosis, of which, when I am in Barcelona, I will send you a large specimen together with other plants. I expect Dr. Stuard will send you something when he botanises the island in April and May because the season right now is too dry and the countryside is too dry and hot. Please send me the books I have asked you for, such as the third volume of Ray, the volume by Mr Sloane, Scotia illustrata, Philosophical Transactions \&c and notify me of the expense so I can send you the money; the requested drugs and, in short, everything new that you receive concerning plants, animals and drugs.

An annotation by Petiver indicates that this letter reached him on 6 November (OS), once again four months after it was written. This letter is irrefutable proof of Salvador's visit to Majorca and Minorca between the spring and summer of 1711 (and not 1712, as was mentioned). It also indicates the scientific objectives of his trip, which were not just limited to plants, although these were the fundamental purpose for his collecting specimens, but also included molluscs and insects. Joan Salvador also went about his work as a naturalist, describing Hypericum balearicum that had been incorrectly identified, according to him, by Clusius, and he communicated this to another naturalist and promised to send him a more adequate specimen. ${ }^{43}$

The Mr Stuard mentioned was almost certainly Surgeon-General Archibald Steward. He was possibly Scottish because, according to Dandy (1958), he had sent Petiver plants in 1699 "brought from the Scots Settlement at Darien". We have no other biographical data although his known period of activity, which Dandy (1958) limited to 1699-1709, can be extended to 1712 .

With regard to Salvador's orders for books, he had already furnished Petiver with a list in his letter of 22 September 1708, together with a bill of exchange to the value of $£ 6$ sterling, with instructions to exceed this quantity if necessary on the understanding that he would make up the difference.

This same letter was confirmed by another, dated 20 September 1711 and probably addressed to Lecaan, of which only fragmentary knowledge is available from one of Petiver's copybooks. ${ }^{44}$ The appalling writing in the copybook makes it very hard to understand.

Dr. Salvadore

Barcel. Sept. 20.1711

I hope $\mathrm{M}^{\mathrm{r}}$ Pet. will be returnd from Holl[and] \& has brought some rarities with him. Pray [illeg.] to him desiring he will send me a [share] of [illeg.] may [illeg.] him. I shall send him diverse rare plants find [in] Majorque \& Minorque with $\mathrm{t}^{\mathrm{e}}$ Myrto Cistus Pennei. $\mathrm{D}^{\mathrm{r}}$ Steward is well \& [illeg.]. [illeg.] I hope [illeg.] some other bookes with Ray Vol. 3. Sloan Hist. Jam.$^{45}$ Sibbald Scot. illustr. prod. ${ }^{23}$ Ray [illeg.] with te charge \& with for a Collect. of Engl. [illeg.] Shells with te Stones \& Mineralls well condicioned [illeg.] my Collect.

The copy of a longer fragment from another of Salvador's letters to Lecaan (dated 20 November 1711$)^{46}$ from another letter copybook is slightly more informative:

$\mathrm{D}^{\mathrm{r}}$. Salvadore $\mathrm{pr}^{\mathrm{t}}$ of his letter to $\mathrm{D}^{\mathrm{r}}$. Lecaan relating to me

Please give my regards to Mr Petiver and tell him that Mr Squire has already unloaded the box marked with a P in Tarragona. I wrote to him, telling him to open it and he told me that it contains Ray's volume 3; 5 or 6 volumes of the Philosophical transactions; dried plants; etc. so no sooner than I have everything in Barcelona I will write him a catalogue of the books that he has sent me in order to send the rest of the money although in the meantime have him send me (or you) the other books that I have asked him for, such as Lister's Historia Conchiliorum in folio, the appendix to Historia animalium Angliae solummodo ${ }^{47}$ and other treatises by Lister on natural history, I already have his Historia Angliae; Synopsis Stirpium Britannicarum by Ray and Methodus 
Insectorum by the same author ${ }^{48}$; Theatrum Botanicum et Paradisus by Parkinson ${ }^{22}$; J. Gerard's Historia Plantarum Emaculata ${ }^{24}$; Sibbald's Scotia Illustrata ${ }^{23}$, De Lapidibus by Laet ${ }^{49}$; Willoughby's Ornithologia and, by Lobel, [Stirpium] Illustrat. ${ }^{50}$ Museum Regia Societatis. All of these books printed in England, together with others that you consider I am lacking and check with Mr Hay if he has sent me any books and, if so, if Willoughby's Museum is amongst them. If he has not sent me them, please pay my deepest respects to $\mathrm{Mr}$ Hay and tell him that I have a large box ready for him but that we are still waiting for the fleet carrying the king to Italy that should leave for England, in particular the Grafton, the ship that was captained by Milord Forlis, and which Mr [Trenet], a friend of Mr Petiver, was on board, and on which I myself returned from Mahon. [illeg.] and I will send the box on this ship. There is another one addressed to you in which you will find the inscriptions from Barcelona for Mr Hay and many other things for Mr Rand, whom I ask you to give my humble regards to, I trust that you send me a share of anything out of the ordinary. I am grateful for the correspondence you obtained for me from Mr Boerhaave, the professor from Leiden, which I have already replied to and I have already raised several [illeg.] him and sent him with the first [illeg.] in flowerpots and prepared a good [illeg.] for him and asked him for some other plants that I hope he sends me.

\section{BROADENING THE NETWORK}

In spite of confusion because of the appalling writing in Petiver's copybooks, this fragment is extremely interesting because it shows how Salvador, probably through Lecaan, had considerably broadened his relations with English as well as Dutch naturalists, or at least with Boerhaave. Various other annotations, which are even more confusing and refer probably to this same letter ${ }^{51}$, seem to demonstrate that Petiver did not understand what Joan Salvador was asking him. The first one says:

Barcel. 9r 20. 1711

I has rec ${ }^{\text {d }}$ a List from [D. S.] $w^{\text {ch }}$ I do not understand for there [illeg.] $w^{\text {ch }}$ no [illeg.] $w^{\text {ch }}$ pray [illeg.] \& let him [illeg.] he desires.

The following note, on the same page, refers to a letter dated 12 December 1711; we cannot determine if it was addressed to Petiver himself or Lecaan.

Dec. 12. 1711

If $t^{\mathrm{e}}$ Grafton comes [not] first away first I will send te box I have [illeg.] so long by another hand. The tables of his G. N. from 50 to 90 [illeg.] explications. The Insects [illeg.], $\mathrm{t}^{\mathrm{e}}$ rest I [illeg.] of a Catalogue. I desire Drogues for my Cabinet, Minerals particularly those of [illeg.] Clay, Earths, Shells \& particularly those of England by Lister $\mathrm{w}^{\mathrm{ch}} \mathrm{y}^{\mathrm{u}}$ know te $\mathrm{t}^{\mathrm{e}}$ [illeg.] for.

This somewhat confusing state of affairs is cleared up by the letter sent directly by Salvador to Petiver that bears the date 10 January $1712^{52}$, which is accompanied by a list of the books actually received by Salvador and another list of those that he still wished to receive and, according to what he says, had already been sent to Lecaan.

I have been waiting some time for a good occasion to send you a large box full of things but as these occasions are so rare; since Admiral Norris left there has been no more and I was in Majorca then. I finally received the box marked P from Mr Squire, in which was the book by Ray and others. At the end of this letter you will find a list of books that I received from you; however I was expecting the others that I particularly asked for: the third volume of Ray's history of plants, the History of the plants of Jamaica by Mr Sloane and others that you must have seen in the letters I wrote to our friend, Dr Lecaan, and so I ask you to buy and send the ones that remain in another list. I expect everything on the fleet next spring, including the drugs, figured stones, shells, minerals, earths, etc. that I also had the honour to request from you in previous letters. Please continue to send me every year the Philosophical transactions, etc. In the last box I found those of the months of January to August 1709 but I see that in different places some things are missing because some page numbers are missing. Please also send me the remaining tables from Gazophilacium, from number 50 to today, with the explanation, and anything else you have printed. I am sorry for the delay in sending the aforementioned 
box. Whenever someone who you know comes, it would be good if you could write to me because it would then be easier to give them whatever I have. Some people of course do not want to carry this kind of things but [illeg.] many plants, that only propagate by cuttings, if you wish me to plant them in boxes. I will gladly do so if you do as I say and let me know by way of known acquaintances that come here.

There was in fact a letter sent by Salvador to Petiver (undoubtedly the one dated 20 November, of which we have knowledge of a fragment) that contained amongst other things an order for some books for Petiver and was probably confirmation of other preceding ones.

Regarding the list of books (transcribed in Appendix, letter 9, p. 169), there is confirmation in Salvador's letter on 22 September 1708 of Scheutzer's Itinera alpina having been received. Most of those confirmed as having been received are conserved in the Salvador library, with the exception of Morison's Historia plantarum, Plukenet's Phytographia ${ }^{53}$, and Phytologia britannica, which appears in the list without an author although it was most probably William How's Phytologia britannica, published anonymously in 1650. Ray's Historia plantarum ${ }^{54}$, the other works quoted as being by Plukenet ${ }^{55}$, Collectanea chimica leidensia (of which there are two different editions $)^{56}$, and Pinax rerum naturalium britannicarum by Merret ${ }^{57}$ are all in the Salvador library.

The requested books also bear out Joan Salvador's profile as a scientist. On the one hand, he insists on completing his collection of books that provide a good understanding of natural history of the British Isles, whence he was expecting to receive more consignments in the future, and which, for him, was an exotic place. Moreover, despite the fact that works on botany predominate (Ray's Synopsis stirpium britannicarum and the third volume of Historia plantarum; Catalogus plantarum quae in insula Jamaica by Sloane; Herball by Gerard; Theatrum botanicum and Paradisi in sole paradisus terrestris by Parkinson; Plantarum seu stirpium icones by L'Obel; Hortus regius blesensis by Morisson; Florilegium novum by de Bry; or Icones plantarum by Tabernaemontanus), he takes care to include those dealing with insects (Methodus insectorum by Ray; Theatrum insectorum by Moufet (olim Moffet)), rocks (De lapidibus by Johannes de Laet), birds (Ornithologia by Willoughby) and other animals (Exertitationes de differentiis \& nominibus animalium by Charleton ${ }^{58}$ ). Finally he asks for Scotia illustrata by Sibbald, Museum regia societatis by Grew and Philosophical transactions. Salvador also declared that possessed of the works by Ulisse Aldrovandi (1522-1605) and Jan (Johannes) Jonston (1603-1675), which were already classics at the time of writing and that must have been incorporated into the family library some years previously by his father (and maybe some of the Aldrovandi volumes by his grandfather). ${ }^{59}$

It was not long before another opportunity presented itself to send a consignment to Petiver from Barcelona. Towards the end of that same January, a vessel, apparently from Mahon en route to England, gave Salvador his long awaited opportunity. Salvador himself expressed it this way in two letters, one dated 26 January $^{60}$ and the other 2 February ${ }^{61}$, both of similar content although each must have followed a different path, one travelling inside of the box that he refers to and the other independently, in all likelihood with the object of avoiding the prolonged delays caused by periods of quarantine and storage in Portsmouth that had been imposed on earlier consignments without Petiver having been informed.

The first letter reads as follows:

Together with [this letter] you will receive a box addressed to you and marked I. P., in which you will find another box with insects, the plants that I brought from Minorca, stones, shells, a Squilla lata (decapod crustacean) and other things that for some time now I have had ready to send you in anticipation of a fleet. As there is no prospect of any, however, I am venturing to take this opportunity. As the enemy occupied almost all of Catalonia last year, botanizing has been impossible, although I hope that I can make a good expedition this 
year and that the country will be freed. So I will try to collect seeds, dried plants and other things for you; I am not sure whether to plant some rare plants in boxes. When one of your friends comes here, I would also like you to entrust them with bringing whatever you can give them and also that you write to me so I can I meet them. I await the next fleet with what I asked you for in the other [letters].

The text of the second one is similar:

I have had the honour to write to you several times that I received the box brought by Mr Squire marked P, in which were the first and second volumes of Historia plantarum by Ray. I desire but to obtain volume three as I have the other two for quite some time now. Nevertheless, please include it together with the others I have requested on several occasions, such as Sloane, Parkinson, Lister, etc. By way of the ship Galera Maria, Captain Daniel Hutchinson [Pritchard] I am sending you the box that I have been keeping for a long time for you with different insects, the plants that I brought from Minorca, shells, stones, a Squilla lata, etc. that I trust will all arrive well conserved. It is addressed to you and bears the marking I. P. On this ship is a surgeon friend of mine from Mahon whose name is Mr Harvick. I am expecting at the first opportunity things such as drugs, shells, books, etc.

We know that Petiver received this consignment relatively quickly from the copy of one of his letters ${ }^{62}$ conserved in one of his copybooks. No other testimony remains as the original is lost, if it ever reached Salvador, bearing in mind the situation that Barcelona was in (together with the rest of Catalonia) following the Treaty of Utrecht.

Dr John Salvadore

$\mathrm{S}^{\mathrm{r}}$ I have received $\mathrm{t}^{\mathrm{e}}$ box $\mathrm{y}^{\mathrm{u}}$ sent by Cap ${ }^{\mathrm{t}}$ Hutchinson with $\mathrm{t}^{\mathrm{e}}$ Plants you collected at Port Mahon $\mathrm{w}^{\text {ch }}$ would have been much more acceptible if had $t^{y}$ not been the remains of these you sent to $\mathbf{M}^{\mathrm{r}}$ Rand one who has published nothing himself nor pleased with any thing I do. D $\mathrm{D}^{\mathrm{r}}$. Sloan, $\mathrm{t}^{\mathrm{e}}$ Secretary of our Royal Society to whom $\mathrm{y}^{\mathrm{u}}$ are obliged for $\mathrm{t}^{\mathrm{e}}$ present he made you (throw my recommendations) of his Natural History of Jamaica, a book you so much desired was in expectation of $\mathrm{t}^{\mathrm{e}}$ duplicates you had so spare rather than to [illeg.] another who is not his friend such a [illeg.] retalliation for his book would have induced him ( $\mathrm{w}^{\text {ch }}$ he had some thought of) to have admitted you a Member of our Royal Society $w^{\text {ch }}$ his interest \& inclination as well as mine are capable of doing we being both this year of the Councele. I had at first some thougths of publishing in our Acta Philosophica the things you sent me, \& given $t^{\mathrm{e}}$ Figures of these $\mathrm{w}^{\mathrm{ch}}$ are not yet done, but to prevent $\mathrm{M}^{\mathrm{r}}$ Rand censure shall leave it to himself who has more leisure.

Nevertheless I will by $\mathrm{t}^{\mathrm{e}}$ next ships made $\mathrm{y}^{\mathrm{u}}$ an ample return for $\mathrm{w}^{\mathrm{t}}$ you have now sent \& perhaps among them some things $\mathrm{t}^{\mathrm{t}}$ neither $\mathrm{M}^{\mathrm{r}}$ Rand or any but my self are capable of retalliating $\mathrm{y}^{\mathrm{u}}$ with, and for the future shall always respect things $\mathrm{y}^{\mathrm{u}}$ come only to my selfe \& Friends rather $\mathrm{t}^{\mathrm{n}}$ to others \& will make a return accordingly.

By $\mathrm{t}^{\mathrm{e}}$ last I sent you severall of $\mathrm{t}^{\mathrm{e}}$ bookes you wrote for $\&$ by $\mathrm{t}^{\mathrm{e}}$ next you shall have most of the rest Viz. Listeri Hist. Conchyliorum \& Appendix, Gerard, Grew, Charlton [sic], Parkinson, Ray, Willuby [sic], \&c and desire you will in $\mathrm{t}^{\mathrm{e}}$ interim order me the Money for $\mathrm{t}^{\mathrm{t}}$ former.

I have sent you inclosed a Catalogue of $\mathrm{t}^{\mathrm{e}}$ English Land and River shells I last sent you by the next $\mathrm{y}^{\mathrm{u}}$ shall have the marines \& any other things I am putting up for you by $w^{\text {ch }}$ you will see how much I am $S^{\mathrm{r}} \mathrm{Y}^{\mathrm{r}}$ most humble Serv ${ }^{\mathrm{t}}$

July 15.1712

J. P.

We are not sure why there is a Latin version of the same letter in another of Petiver's copybooks, the original of which is presumably lost. ${ }^{63}$

While this consignment was en route, on 15 April 1712, Salvador sent another letter to Petiver. ${ }^{64}$ We do not know when Petiver received this letter, in which Salvador yet again assured with inexhaustible optimism that, as soon as the enemy lifted the siege, he was thinking of going to the Pyrenees, which would result in a truly splendid consignment of plants and seeds.

I trust you received a box with plants from the Balearic Islands, shells, a Squilla lata, etc. from the ship named Galera Maria, Captain Daniel Hutchinson, that left this port some time ago. I am going to Montserrat in a few days time and I shall try to bring back some plants for you and, the weather and the enemy permitting, 
I hope to go to the Pyrenees mountains and I promise to send you a share of the plants, seeds, etc. that I find. I am expecting a consignment from you on the first ships, in particular the books that I asked for in my earlier letters.

\title{
THE END OF THE WAR
}

When the end of the War of the Spanish Succession was being negotiated in Utrecht, communications were increasingly difficult for the inhabitants of Barcelona, despite the fact that English maritime supremacy, as a result of the occupation of Gibraltar and Minorca, still made sea communications between Barcelona and the English ports relatively safe. During the first few months of 1712, the allied armies still held off the Bourbon forces in southern Catalonia although the French had occupied a large part of the territory in the north, including Gerona. The first ceasefire agreement between France and England was reached in June 1712 and, from 17 July onwards, the English forces on Spanish soil began to make their way to the designated ports of embarkation to be repatriated. This may explain why Jan Lecaan again passed through Barcelona, and Salvador took advantage of this to send letters with him to his English friends. At least two of these, one addressed to Petiver and the other to Sloane and both dated 22 August 1712, still exist. Nothing is known concerning the vicissitudes of Lecaan's return to England, although we do know from a hand-written note by Petiver that the letter ${ }^{65}$ reached him more than six months later on 30 March 1713 (OS), just the day before the signing of the Treaty of Utrecht (10 April $1713 \mathrm{NS}$ ). The letter quite naturally ignores Petiver's criticisms in the letter of because he more than likely never received it although the reference to certain shells received does raise the question whether, as a result of the ceasefire and the urgency of sending a fleet to repatriate the English troops, the speed by which the consignment arrived did for once exceed all expectations. The apology in the letter sent to Petiver, and the fact that he wrote directly to Sloane for the first time, through Lecaan, do lead one to conjecture.

\begin{abstract}
A few days ago I received through Mr Quait a small box with shells that I am humbly grateful to you for, and I also ask you again to send me a share of your wonderful things. As our country is not very abundant in a variety of things I cannot send you everything that I could although I [can] at least let you know about everything that I find. I cannot always be in the countryside or be going around the country and this is another thing that prevents me from finding more things, above all because the country is partly occupied by the enemy, and I assure you that I am very regretful that I cannot send you everything you would like. For these reasons please excuse me and if you would continue to send me a share of all the things that different people bring you every day from India and other places, but here I am collecting all alone. I await whatever you wish to send, Sir.
\end{abstract}

The letter to Sloane ${ }^{66}$ is also very short but the interesting thing is that it informs Sloane that he still has not received Catalogus plantarum quae in insula jamaica, that he had repeatedly asked Petiver for. He openly proposes direct exchange with the English naturalist, without going through the irksome intermediary that Petiver sometimes was.

The renown of your most excellent merit and your curiosity for botany and for all knowledge about natural history have for some time led me to want to take the opportunity to congratulate you on this. Dr Lecaan has now encouraged me to write respectfully to you as he has told me to make you a good collection of all natural things (he also added that you are giving me a copy of your book, which I am impatient to receive). I vow to do everything I can to gratify you in this respect, in particular with regard to the things from my country, and because I have not had the time to collect more, I am just sending some things that Dr Lecaan will give you, in the hope that you will also send me a share of your good collections of things from the Indies, that I imagine you have an abundance of. Please forgive the liberty I take and willingly accept this offer of sincere 
friendship and my best offices in the commerce of these things, and rest assured that I shall always be prepared to send you whatever you desire from here.

Despite the difficulties and obstacles imposed by the war, Petiver continued to send consignments although not all of them reached Salvador promptly. Two documents, one sent ten months after the other, are the only testimony of a consignment containing some American plants (only one - from Virginia - has been conserved in the Salvador herbarium) ${ }^{67}$ and books (most of which are conserved in the Salvador library), which was the last that Petiver would send during wartime. We know of the first of these documents, which was written in Latin, only from the copy conserved in one of James Petiver's copybooks. ${ }^{68}$

I wanted to take the opportunity to send you a consignment, as I promised in exchange for yours. It would have been more abundant had it not been for the sudden departure of Mr Naper, the illustrious surgeon. Nevertheless, you will find about forty American plants, most of them from Virginia, the rest from Jamaica. I would rather have sent better specimens but coarse and ignorant hands collected them because there are very few in those places that know anything about botany and even fewer who like to collect plants or that even have any idea why this is done. I have added to these around fifty English sedges and rushes and similar herbs regardless of the fact of their similarity in appearance or their being the same sent by you from Port Mahon, from where not long ago I received two volumes from someone else and daily expect other volumes). Although I do not have too many, I will naturally send you duplicates of those roots I sent you that are at least rare and no-one else has. As for the content of this consignment, you can just imagine the wonderful specimens from Asia, Africa and America that nobody else but myself can send you that you will receive in the next consignments. In exchange, I hope that, in the future, you do not fail to take advantage of any opportunity to obtain for me collections of animals, vegetables and fossils from these parts of the two Indies with which the Spaniards commerce, especially Peru and Mexico, this latter place which Hernández and others have illustrated. In the meantime, I would be very grateful for anything that you may find wherever you go in your country, as I was not so long ago with the Squilla lata rondeletti and the crab that you sent me.

Some time ago I sent you, and am now resending, a catalogue by this author on crustacean animals that I would like to see and back then I sent you a more or less convenient sample of the few that we have on our coasts, of which I sent you a catalogue not very long ago. I am going through Synopsis Avium et Piscium written originally by Mr Ray ${ }^{69}$ and if at some early opportunity you would send me the catalogue of the genera of all those that are to be found in your country I would add them to it. I know Belon and Rondelet from [illeg.] also you could possibly add something new. The animals themselves, mainly the smallest ones, are easy to send in jars with liquor or some other spirit, I add some drawings of the new ones, together with the observations I have been sent. I can assure you without hesitation that our Royal Society is very inclined to promoting all areas of natural history and stimulating all those interested in it. Remind me in an annex the books that I have already sent you and in the next ships I will add everything you ask for, together with others that [illeg.] already [illeg.]. In the future (if you think it is all right to do it so often) I should collect some natural curiosity or animals, vegetables or fossils every month for you. To start with, at the next opportunity you will receive an extensive collection of medical material according to the preferences given in your catalogue.

It is likely that, due to the wartime circumstances, Salvador never received this letter; the original is not among Petiver's correspondence conserved in the Salvador collections. Another of Petiver's extant letters ${ }^{70}$, letters from ten months later, refers to the same matters and we know that Salvador did not receive this one until several months after the fall of Barcelona on 11 September 1714.

Worthy Sir

My last to you was by $\mathrm{M}^{\mathrm{r}}$ [Naper] Surg ${ }^{\mathrm{n}}$ at Port Mahon, by whom I sent you ab 40 Specimens of American Plants, mostly from Virginia, the rest Jamaican with 50 English Cyperi, Cyperoides, Junci \& Grama Juncea which I hope you have receiv'd, with my letter to which I refer you. By Sig ${ }^{\mathrm{r}}$ Bernardo Peyralou of Alicant, a friend of $\operatorname{Sig}^{r}$ Romani I now send you in the Winder Frigat Cap ${ }^{t}$ John Worry Comand a Collection of ab 40 Jamaica grasses, most of which I hope will be altogether new to you.

I shall be glad to see what Plants you have gathered att Montserrat \& on the Pyrenean Mountains, particularly those which $D^{\mathrm{r}}$ Mycon mentions \& Figures in his Historia Lugdunensis.

I have acquainted Sig ${ }^{\mathrm{r}}$ Romani with $\mathrm{y}^{\mathrm{r}}$ Bill of 19 Pounds, ten shillings \& eleven pence, which I hope you will 
give him immediate Order to pay me, \& the rest of the Books you desire I will send by all Opportunitys. The Materia Medica \& the Officinal Plants, which I promise you in my last, I will send by the next Shipping.

By $\mathrm{M}^{\mathrm{r}}$ Naper I sent you Parkinson's Herbal \& Paradisus Terrestris, ${ }^{22}$ Lister's Historia Conchyliorum edit: opt: Grew's Musaeum, ${ }^{71}$ Moufet Insectorum ${ }^{72}$ \& Ray's Synopsis Stirp: Britannic: ${ }^{73}$

I have lately finish'd 100 Tables of my Gazophylacium which I now send you compleat, as also 50 Tables of $\mathrm{M}^{\mathrm{r}}$ Ray's English Herbal, to both of which if you can gett me 5 Subscribers you will both oblige me \& have a Title to a $6^{\text {th }}$ Book gratis: And as soon as you send me their Subscriptions, Names and Titles, I will return you their Dedications \& as many Books as you want in the interim you may lett them have yours if you desire it, \& I will supply you again by the next. I beg I may hear from you by all opportunities, \& you shall from me who am

Worthy $S^{r} Y^{r}$ most affectionate Friend \& humble servant

London Augt: ${ }^{\text {th }} .1713$

James Petiver

You may please to direct for me

Apothecary to the Charteraux \& Fellow of the Royall Society. London.

This letter must have reached Salvador quite some time after 11 September 1714. While Barcelona was being besieged by the Bourbon forces, ships with cargo bound for the city were unloaded in Alicante and Mahon. We know about this from the two following letters from Salvador, the first undated and addressed to John Lecaan and very likely sent between 12 September to 6 December $1714^{74}$, and the second, addressed to James Petiver, written on these latter date..$^{75}$ The two are transcribed below and portray Joan Salvador as being quite matter-of-fact, talking about past setbacks as being the most trivial things in the world and without exaggerating anything, although he does give some moving details concerning his situation and conduct during an episode in the defence of Barcelona, as a result of which Petiver believed him to have been killed, as we shall see.

\begin{abstract}
It is a long time since I have received any news from you and I do not know if you are in England or somewhere else. During the siege, I wrote to you twice to the address in Majorca, and the letters were then sent to Minorca, but I do not know if you received them. You must undoubtedly have heard about our terrible siege but, thank the Lord, our house is still standing. My brother and I stayed in the city, my father and the rest of the family were away, and all are well and humbly send their regards. They have just informed me from Port Mahon that during the siege something was unloaded from the frigate Winder for me. I hope it is the books and other curiosities from Mr Rand, which some time ago they wrote saying they would send them at the first opportunity. When I see the tally of everything, I will make [illeg.] your money, and also something for the rest of your merchandise. Please give my regards to Mr Hay and send me his news. Whatever you can collect, I would be indebted to you.
\end{abstract}

The letter, as can be seen, shows Joan Salvador to have diversified his relations in London, quite the opposite of what Petiver wanted at that time. As we have seen, Petiver tried to control Salvador's exchanges with England with a mixture of promises and threats, and to prevent him from having connections with people who were not to his liking.

After all the distress and difficulties that we suffered during such a long siege, I have received one of your letters, of 10 August 1713 with a package of books: Gazophylacium Naturae Tabulae, Aquatilium Animalium Amboinae, Ray's English Herbal, Synopsis Avium et Piscium, Methodus Insectorum and Musei Cent. ${ }^{76} \mathrm{I}$ have also seen the books and catalogue that you say were sent on the frigate Winder. After having written to Alicante and Mahon to find out if this ship arrived during our siege and if anything had been unloaded for me from it, I later found out that many things were unloaded from it in Barcelona, amongst which there was something for me. I am waiting for the reply whether they are the books from your catalogue or others. I have also seen the cost of the books, the value of which I will send you at the first opportunity, either by means of Mr Romaní, or by Messers Shallet and Crowe. I also request you to inform me if, four or five years ago, you received the bill of exchange for $£ 6$ sterling that Messers Shallet and Crowe had to give you. I hope to gather plants in the Pyrenees and Montserrat this spring and I shall try to dry all the rare plants that I find for you, especially the 
ones that Micó mentions. I am beginning to put my small cabinet in order again, which I had removed from the house for fear of the bombs. I shall put some aside for you. I would be very grateful if you could send me the drugs for the study of medicine and the rare plants. I received the tables from Ray's English Herbal up till number 50 but I am missing ten, numbers $1,2,3,4,5,6,7,8,9$ and 10 . I would be very grateful if you could send me them, and also inform me whether you have the rest [from 50 onwards]. I would also like the Icones et Nomina Animalium Amboinae, I find it beautiful and very well engraved although I would be even more grateful if, of all the shells that you can find, shown in this catalogue, the knowledge of which I am very keen on, if you could buy a good collection, meaning one or two of each species. I hope you can do me this favour, and to collect all the curiosities of every kind that you receive, of both animals and minerals [illeg.] \&c and thereby I shall be indebted to you.

This letter (and the following one from Petiver, in which he declares his joy at discovering that his friend had survived the siege of Barcelona in 1714) marks a watershed between the two stages of the correspondence between Salvador and Petiver: one corresponding to the War of the Spanish Succession, covered by this paper, and the other corresponding to the post-war period up until the death of James Petiver in 1718, which will be dealt with elsewhere.

With the reply to this letter ${ }^{77}$, which initiates a particularly productive stage in terms of the exchange of letters, and natural and bibliographical materials, between Joan Salvador and James Petiver, we bring this paper to a close, which will also serve as the starting point for a subsequent one that will cover the four-year correspondence between them during the postwar period. One peculiarity of this letter is that it is written on the back of two of Petiver's printed tables. Here we give just a transcription of the text of the letter, the commentaries being left for the paper on the period following the War of the Spanish Succession.

London April the $25^{\text {th }} 1715$

My Very Worthy Friend

$\mathrm{S}^{\mathrm{r}}$ It was [with] no small Joy when I rece'd $y^{\mathrm{r}}$ signed Decemb. $6^{\text {th }} 1714$ with yo ${ }^{\mathrm{r}}$ own hand (wich I was formerly [illeg.] well acquainted with) hearing you have been dead, reading that one of $\mathrm{y}^{\mathrm{r}}$ name was killed upon the Breach, I hope now [illeg.] shall have a more frequent Correspondence together \& be assured you shall suddenly receive [illeg.] Plants, Shells, \&c some of which I am sure you never saw before. I write this to save postage on Tables of Plantae Submarinae Mediterranei wich I have taken out of Barrelieri Icons. [I] hope you will find most of them on your Shoars which I should be glad to see I have allso figured all the grasses which he had observed $\mathrm{ab}^{\mathrm{t}}$ Rome, which are $\mathrm{ab}^{\mathrm{t}} 50$ these I will send you by my next, as allso my Pterigraphia Americana containing the compleat figures of near 200 Rare American Ferns taken mostly from Plumier's Hist. des Fouguieres ${ }^{78}$ to which I have added divers Sea productions \& some Animalls, I am now graveing 50 Medicinall Plants from Peru \& Chili Coppied from Feuillé Designs ${ }^{79}$, I must desire to know what Conveniences you have to send to Madrid, because with $y^{r}$ Collections I shall have an Occasion to send some Things to Mons ${ }^{r}$ Riquere, the Kings Apothecary, D ${ }^{r}$ Burlett his Premier Physician \& others, from whome I have rece'd some seeds by my Lord Lexington our late Ambassadour \& [illeg.] promised severall other things, I [was] some Time before the Seige of Barcelona with $\mathbf{M}^{\mathrm{r}}$ Romani who told me I might suddenly expect the Mony from you, which I supose the times prevented, nor have I before or since [illeg.] the Mony you mention for $\mathrm{M}^{\mathrm{r}}$ Crower Shallet, the sume I last sent you was 23 pounds, 4 shillings \& 5 pence, which will [illeg.] me into a Condition to goe vigorously on with the rest of Mr Ray ${ }^{\text {s }}$ English Plants, afterwhich I intend to figure our Brittish Submarines, Fungi, Mosses, Filices, Gramina, Cyperi \& Junci, I am not a little bigg with the expectations of many curious Plants, Insects \& Fossills you will find in yo $^{\mathrm{r}}$ Travells to the Pyrenees \& Montserrat \& shall make an Ample Return for what of them I shall receive from you \& with yo ${ }^{r}$ Leave shall figure all such Things [....] are new or peculiar to these Mountains. I should be glad to know if you have any Correspondence with $\mathrm{D}^{\mathrm{r}}$ Nissole who I hear had printed a Botanicum Avinionense which if you can procure me I will pay the Chargo off, I hope now you will have frequent opportunities of sending Collections of Insects, Shells, Fossills \& Plants with their fresh seed or fruit, for which by every shipping,I will make you a Suitable Return who am

Worthy S/ $\mathrm{Yo}^{\mathrm{r}}$ very Affectionate Friend \& Humble Serv ${ }^{\mathrm{t}}$

James Petiver

Mons ${ }^{\mathrm{r}}$ Jean Salvadore Apotiquaire \& Botaniste tres celebre A Barcelone

avec celerité 


\section{CONCLUSION}

The correspondence between Joan Salvador and James Petiver (complemented by some letters related to both correspondents addressed to Hans Sloane or exchanged with John Lecaan) is revealing as regards the personality and scientific interests of each of them. The Catalan naturalist, until now little known outside Catalan and Spanish botanical circles, manifests himself as a young man studious of natural history and with a solid scientific training, acquired from the best possible teachers of his time (Magnol, Tournefort, Tilli, Triumfetti). But the circumstances of the Spanish Succession war prevented him from communicating with the French botanical circles where he had received his training and thus he began to cement relationships with the naturalists of Catalonia's allies (mainly England and the Netherlands) in the defence of the candidature of Charles of Austria to the throne of Spain.

Throughout the eight years of the war, he acquired more security in his own capacities, explored territories until then little known to naturalists (Majorca and Minorca), sought out new relationships, and came to be on much more familiar terms with his interlocutor. Petiver, a dedicated naturalist, ten years older than Salvador, treated him at first with a certain coolness, although he was interested in the possible benefits of this new relationship, and ended up treating him as "Botaniste tres celebre", the very famous botanist.

\section{ACKNOWLEDGEMENTS}

The authors are glad to acknowledge the help of Fundació Enciclopèdia Catalana (Barcelona) in the early stages of this work. Later on (2003) it was partly supported by the SYS-Resource Project of the European Union with a grant to study Salvadorian materials in the Sloane Herbarium (Natural History Museum, London). We are also very grateful to the editor of the Archives of Natural History for the orientation received, as well as to the referees who read the initial versions of this article and have favoured us with their remarks and indications. We wish also to give our warmest thanks to Charles Southgate and Samuel Pyke for his help in checking the text.

\section{NOTES}

${ }^{1}$ The origin of each transcribed document is given. Transcription of the originals of Joan Salvador was not especially difficult and only slightly more so (due, above all, to the large number of abbreviations) in the case of Petiver's. On the other hand, there were greater difficulties when dealing with the letters by both correspondents, the content of which was solely conserved in Petiver's copybooks, due to the untidy writing and an even greater proliferation of abbreviations; thus, despite our efforts, it was not possible to decipher certain unclear passages in the documents. One should also bear in mind, concerning the dates of the correspondence transcribed here, that the Gregorian calendar had still not been adopted in England, so the dates in the heading of each correspondent's letters relate to different calendars; note is made of this in each case.

${ }^{2}$ J. Salvador (JS) to J. Petiver (JP) 24 December 1706 (NS): original ms, Sloane mss 4064, f. 124. British Library (BL), London (hereafter BL-Sloane).

${ }^{3}$ Original text of that letter (and that of other documents written in French or in Latin) is transcribed in the Appendix (see pp 166-173) at the end of this paper.

${ }^{4}$ Noted as having been received by Petiver on 16 March 1707 (OS).

${ }^{5}$ Neither was any copy found in Petiver's copybooks.

${ }^{6}$ JP to JS, 21 April 1708 (OS): original ms, Institut Botànic de Barcelona, Correspondence of Joan Salvador (hereafter IBB-JS).

${ }^{7}$ Musei petiveriani centuria ... rariora naturae, published between 1695 and 1703, were lists of 100 items from Petiver's collections. There are three bound copies in the Institut Botànic de Barcelona Salvador library (hereafter IBB-SL); one lacks a page and bears the inscription "James Petiver. Ex dono autoris", which probably means that 
it is the copy mentioned here.

${ }^{8}$ Each Gazophylacium naturae et artis consisted of a printed page with the drawings of a series of plants and animals from Petiver's collections, accompanied by a notebook with the relevant explanation of each drawing. They generally dealt with more or less one particular subject, each with a dedication to one of Petiver's friends or correspondents, either because it was the person who had sent him the specimens that appear or because he wanted to honour or flatter them in this way. The first volume, mentioned here, is in IBB-SL; it is bound with the second one, and contains the first five decades (series of ten), published between 1702 and 1704, although the joint index to the ten decades as published bears the date 1711. Curiously enough, the inscription on the first page was changed and instead of the vignette corresponding to the original addressee, which appears on the printed leaflet explaining the series of ten sheets in the decade, there is a dedication to Joan Salvador.

${ }^{9}$ Scheuchzer (1708): in IBB-SL.

${ }^{10}$ JS to JP, 22 September 1708 (NS): BL-Sloane 4064, ff 176-177.

${ }^{11}$ JS to JP, 8 November 1708 (NS): BL-Sloane 4064, f. 184.

${ }^{12}$ John Lecaan (hereafter JL) to JP, undated: BL-Sloane 4064, f. 189.

13 JP to JL, 3 October 1708 (OS): BL-Sloane 3337, f. 10.

${ }^{14} \mathrm{JL}$ to JP, 10 February 1709 (NS): BL-Sloane 4064, f. 191.

${ }^{15}$ More than likely "frame". Lecaan, who was not a native English speaker, may have mistaken "frame" with "freak of nature" (a common expression at that time).

${ }^{16}$ JP to JL, 17 February 1709 (OS): BL-Sloane 3337, ff 91v-92r.

17 JP to Mrs. Lecaan, 17 February 1709 (OS): BL-Sloane 3337, f. 92 r.

18 JP to JL, 29 September 1709 (OS): BL-Sloane 3337, f. 60 r.

${ }^{19}$ Lecaan, following the frequent use in English sources at the time, used "Port Mahon" to refer to the city and port of Mahon (Maó) as well as the entire island of Minorca.

${ }^{20}$ More than likely he was referring to the Low Countries, where Lecaan came from.

${ }^{21}$ JS to JP, 6 January 1710 (NS): BL-Sloane 4064, f. 218.

${ }^{22}$ This must have been two books: Parkinson (1640) and Parkinson (1629). Neither has been traced in IBB-SL or in the library of the University of Barcelona (hereafter UBL), where some of the books belonging originally to the Salvador library are to be found.

${ }^{23}$ Sibbald (1684): three volumes in IBB-SL.

${ }^{24}$ This could be Gerard (1597) or, more probably, the revised edition (Johnson, 1633): not traced in IBB-SL.

${ }^{25}$ JS to JP, 26 February 1710 (NS): BL-Sloane 4064, f. 224.

${ }^{26}$ JP to JS, 9 February 1709/10 (OS): BL-Sloane. 3337, ff 79r-80r.

${ }^{27}$ An abbreviation of ream, equivalent to 20 quires, each one having 24 sheets.

${ }^{28}$ JL to JP, 20 April 1710 (NS), Tarragona: BL-Sloane 4064, f. 226.

${ }^{29} \mathrm{JP}$ to JS, 29 August and 5 September 1710 (OS): IBB-JS.

${ }^{30}$ JP to JS, 5 September 1710 (OS): BL-Sloane. 3337, ff 82r-83r.

31 The transcription was made from the original letter, which has the list of plants referred to in the second paragraph, followed by a postscript.

32 Joan Salvador's father.

${ }^{33}$ At this point in the copybook version, f. $82 \mathrm{r}$ is full and it continues on $\mathrm{f} .82 \mathrm{v}$.

${ }^{34}$ At this point in the copybook version, f. $82 \mathrm{v}$ is full and it continues on f. $83 \mathrm{r}$.

${ }^{35}$ JS to JP, 12 February 1711 (NS): BL-Sloane 4064, ff 254-255.

${ }^{36}$ Not all of the Aldrovandi volumes that are in IBB-SL were in the Salvador Library at the time of this letter because some bear ex libris from the Santa Caterina convent in Barcelona, the Royal College of Surgeons of Barcelona and even individuals (Fermí Puals and Josep Jeroni Besora), and thus it is possible they were acquired later on (this is certain in the case of the Royal College of Surgeons, which was not founded until 1760). For example, it is known that Josep Jeroni Besora (c. 1600-1665), canon of Lleida and president of the Generalitat de Catalunya (Catalan Parliament at this time) in 1656, bequeathed his library of 5,567 books to the convent of Sant Josep del Carme Descalç in Barcelona, on the condition that it be made public, but we do not know why some of his books are in the Salvador library. One possibility is that this happened with the "desamortización" (sale) of 
Church properties (including convent libraries) at the beginning of the nineteenth century. The Aldrovandi volumes in IBB-SL that apparently did not form part of any other library are Aldrovandi (1599-1603, 1602, 1605-1606, $1616,1621,1642,1648,1663,1668)$.

${ }^{37}$ This was undoubtedly Jan Jonston (1603-1675), a Polish doctor and naturalist of Scottish origin. Two of his books are in IBB-SL (together with another that forms part of the collection, which is currently in UBL), although there were probably not in the Salvador library when this letter was written because they are both late eighteenth-century editions. It is therefore impossible to make any conjecture concerning the book by this author that Salvador refers to.

${ }^{38}$ This was very probably the Jesuit Filippo Buonanni (1638-1725). Buonanni (1684) is in IBB-SL and Salvador may have acquired it in Italy.

${ }^{39}$ This must have been Karl Nikolaus Lang (1670-1741) from Lucerne, a Swiss naturalist and friend of Tournefort with whom Joan Salvador and his father maintained correspondence; a few of their letters still exist. None of his works are currently in IBB-SL. The work that Salvador refers to here must be Lang (1708).

${ }^{40}$ His disbelief is not surprising, more especially as Tournefort died when he was only 53, the victim of a traffic accident (he was trapped between a wall and a cart axle on a Paris street).

${ }^{41}$ This letter arrived the following April: see JS to JP, 10 January 1712.

${ }^{42}$ JS to JP, 30 July 1711 (NS), Mahon: BL-Sloane 4065, f. 1.

${ }^{43}$ The main epithet in the Salvadorian name (balearicum) coincides with the one adopted for this plant by Linnaeus (1753: 783). We do not know if Linnaeus adopted it simply because of the geographical distribution of this plant or because he took into account the name given by Joan Salvador; he may have seen specimens with the name given by Salvador in herbaria that he visited in London or Leiden. Magnol (1720: 260) and Linnaeus (1753: 783) called it Hypericum vel Ascyrum frutescens, magno flore, and transcribed Salvador's description from a specimen sent to him from Minorca. The Linnaean type is labelled "Habitat it Majorca", and therefore cannot be the same sheet, but Linnaeus was not ignorant of the fact that the plant was present in both Balearic Islands and knew about the description by Joan Salvador.

${ }^{44}$ JS to [JL?], 20 September 1711 (NS): BL-Sloane. 3338, f. 31. Two more short annotations appear on the same folio, referring to Joan Salvador's orders, which are also difficult to read, corresponding to Salvador's letters dated 20 November 1711 and 12 December 1711.

${ }^{45}$ Sloane (1696): in IBB-SL.

${ }^{46} \mathrm{JS}$ to JL, 20 November 1711 (NS): BL-Sloane 3338, f 27.

${ }^{47}$ Lister (1678): in IBB-SL. No copy was found of either Lister (1685-1692, 1692-1697) nor Goedaert (1685).

${ }^{48}$ Ray $(1690,1705)$ : both in IBB-SL.

${ }^{49}$ Laet (1647): not in IBB-SL.

${ }^{50}$ L'Obel (1655): in IBB-SL.

${ }^{51}$ JS to JP, 20 November 1711and 12 December 1711 (NS): BL-Sloane.3338, f. 31.

52 JS to JP, 10 January 1712 (NS): BL-Sloane 4065, ff 13-14.

${ }^{53}$ Plukenet (1691-1692): the copy from the Salvador library is in UBL.

${ }^{54}$ Ray (1693-1704): in IBB-SL.

${ }^{55}$ Plukenet $(1696,1700)$ : in IBB-SL.

${ }^{56}$ Anonymous (1684, 1696): in IBB-SL.

${ }^{57}$ Merret (1667): in IBB-SL.

${ }^{58}$ This was undoubtedly Charleton (1668) (not 1638 as Salvador claimed) which is in IBB-SL. A revised and extended edition was published in 1677 entitled Exertitationes de differentiis \& nominibus animalium and it seems that Salvador mixed up the dates and titles.

${ }^{59}$ Books in IBB-SL include, for example, copies of Aldrovandi's Bologna edition of the 1599-1603 volumes on birds, the Bologna 1606 volume on molluscs, crustaceans and coelenterates. Also in UBL, originally from the Salvador library, are copies of the volumes on birds of the Frankfurt edition of 1610-1613 and the Bologna edition of 1612 on fish. On the other hand, all of Jonston's books in IBB-SL are editions that were published after Joan Salvador's death (see note 37).

${ }^{60}$ JS to JP, 26 January 1712 (NS): BL-Sloane 4065, f. 17. 
${ }^{61}$ JS to JP, 2 February 1712 (NS): BL-Sloane 4065, f. 20.

${ }^{62}$ JP to JS, 15 July 1712 (NS): BL-Sloane 3338, ff 87v-88r.

${ }^{63} \mathrm{JP}$ to JS, 15 July 1712 (NS): BL-Sloane 3340, ff 222v-223r. The Latin version is the same, apart from slight changes, as the English version.

${ }^{64}$ JS to JP, 15 April 1712 (NS): BL-Sloane 4065, f. 34.

${ }^{65}$ JS to JP, 22 August 1712 (NS): BL-Sloane 4065, f. 52.

${ }^{66}$ JS to H. Sloane, 22 August 1712 (NS): BL-Sloane 4065, f. 83.

${ }^{67}$ IBB: Salvador Herbarium, sheet 109.

${ }^{68} \mathrm{JP}$ to JS, 14 October 1712 (NS): BL-Sloane 3340, ff 223r-225r.

${ }^{69}$ Ray (1713): copy in IBB-SL was possibly sent by Petiver.

${ }^{70}$ JP to JS, 10 August 1713 (OS): IBB-JS.

${ }^{71}$ Grew (1681): in IBB-SL.

${ }^{72}$ Moufet (or Moffet) (1624): not traced in IBB-SL or UBL.

${ }^{73}$ Ray (1690): in IBB-SL (see note 49).

${ }^{74} \mathrm{JS}$ to JL, undated: BL-Sloane 4067, f. 134.

75 JS to JP, 6 December 1714: BL-Sloane 4067, f. 186.

${ }^{76}$ Of these books, the following are in IBB-SL: Petiver (1713; 1695-1703; 1702-1711); Ray (1713; 1705).

77 JP to JS, 25 April 1715 (OS): IBB-JS.

${ }^{78}$ This is undoubtedly Plumier (1705) published posthumously one year after Plumier's death: not in IBB-SL.

${ }^{79}$ Petiver was clearly up-to-date concerning publications because the first volume of Feuillée (1714-1726) had just been published in 1714. The three volumes are in IBB-SL.

\section{REFERENCES}

ALBERTÍ, S., 1964 L'Onze de Setembre. Barcelona: Albertí. Pp 467; 12 plates.

ALDROVANDI, U., 1599-1603 Ornithologiae, hoc est de avibus historiae libri XII. Bologna: F. de Franciscis. Pp 560.

ALDROVANDI, U., 1602 De animalibus insectis libri septem. Bologna: G. B. Bellagamba. Pp 767.

ALDROVANDI, U., 1605-1606 De reliquis animalibus exanguibus libri quatuor. Bologna: G. B. Bellagamba. Pp 593.

ALDROVANDI, U., 1610-1613 Ornithologiae hoc est, de avibus historiae libri XII. Frankfurt: N. Bassaeus. Pp 560.

ALDROVANDI, U., 1612 De piscibus libris V et de cetis lib. unus. Bologna: G. B. Bellagamba. Pp 366.

ALDROVANDI, U., 1616 De quadripedibus solidipedibus volumen integrum. Bologna: V. Benacci. Pp 425.

ALDROVANDI, U., 1621 Quadrupedum omnium bisulcorum historia. Bologna: J. S. Bonomi. Pp 1040.

ALDROVANDI, U., 1642 Monstruorum historia, cum paralipomenis historiae omnium animalium. Bologna: M. A. Bernia. Pp 748

ALDROVANDI, U., 1648 Musaeum metallicum in libros IIII distributum. Bologna: M. A. Bernia. Pp 979.

ALDROVANDI, U., 1663 De quadrupedibus digitatis vivparis libri tres. Bologna: M. A. Bernia. Pp 718.

ALDROVANDI, U., 1668 Dendrologia naturalis, scilicet arborum historiae libri duo. Bologna: G. B. Ferroni. Pp 660.

ALLEN, D. E., 2004 James Petiver (c. 1665-1718), in volume 43: 894-896, MATTHEW, H. C. G. and HARRISON, B. (editors), Oxford dictionary of national biography. Oxford: Oxford University Press.

ANONYMOUS, 1684 Collectanea chimica leidensia. Leiden: H. Brummond. Pp 506

ANONYMOUS, 1696 Collectanea chimica leidensia. Leiden: C. Boutesteyn \& F. Haaring. Pp 228.

BOLÒS, A. de, 1946 El herbario Salvador. Collectanea botanica 1 (1): 1-8. 
BOLÒs, A. de, 1959 Nuevos datos para la historia de la familia Salvador. Real Academia de Farmacia de Barcelona. Discursos de recepción 3: 7-50.

BUONANNI, F., 1684 Recreatio mentis et oculi in observatione animalium testaceorum curiosis naturae inspectoribus. Rome: Varesi. Pp 270; 7 plates.

CAMARASA, J. M., 1989 Botànica i botànics dels Països Catalans. Barcelona: Enciclopèdia Catalana. Pp 269.

CAMARASA, J. M., 1995 Salvadorianae, II: Les Jussieu et les Salvador. Deux families de naturalistes au début du XVIII ${ }^{\mathrm{e}}$ siècle, pp 69-102 in LAISSUS, Y. (editor), Les naturalistes français en Amérique du Sud, XVI $-X I X^{e}$ siècles. Actes du $118^{e}$ Congrès national des sociétés historiques et scientifiques. París: Comité des Travaux Historiques et Scientifiques.

CAMARASA, J. M., 2000 Salvadorianae III. Una descripció prelinneana de Silene niceensis All., deguda a Jaume Salvador i Pedrol, a l'edició de 1686 del Botanicum Monspeliense de Pèire Magnol. Collectanea botanica 25 (2): 245-253.

CAMARASA, J. M., 2004 De col·lecció privada a museu públic. El Gabinet Salvador de l'Institut botànic de Barcelona. Afers 49: 721-727.

CHARLETON, W., 1668 Onomasticon zoicon: pleorumque animalium differentias \& nomina propia pluribus linguis exponens. Cui accedunt mantissa anatomica; et quaedam De variis fossilium generibus. London: J. Allestry. Pp 309; 4 plates.

DANDY, J. E. (editor), 1958 The Sloane herbarium. London: British Museum (Natural History). Pp 246; 46 plates.

DESMOND, R., 1977 Dictionary of British and Irish botanists and horticulturists, including plant collectors and botanical artists. Third edition. London: Taylor and Francis. Pp 745.

FEUILLÉE, L., 1714-1726 Journal des observations phyiques, mathematiques et botaniques faites par ordre du Roy sur les côtes orientales de l'Amerique meridionale et dans les Indes occidentales. Paris: P. Giffart. 3 volumes.

GERARD, J., 1597 The herball, or generall historie of plantes. London: Bonham \& John Norton. Pp [xviii], 1392, [72].

GOEDAERT, J., 1685 De insectis in methodum redactus, cum notularum additione, opera M. Lister; item appendicis ad historiam animalium angliae eiusdem M. Lister altera editio hic quoque exhibetur, una cum scarabaeorum anglicanorum quibusdam tabulis mutis. London: S. Smith. Pp 356.

GREW, N., 1681 Musaeum regalis societatis. Or a catalogue \& description of the natural and artificial rarities belonging to the Royal Society ... . London: W. Rawlins. Pp 388.

IBÁÑEZ, N., MONTSERRAT, J. M., SORIANO, I. and CAMARASA, J. M., 2006 Plant material exchanged between James Petiver (ca. 1663-1718) and Joan Salvador I Riera (1683-1725). I. The Balearic plants conserved in the BC-Salvador and BM-Sloane herbaria. Notes and records of the Royal Society 60: 241-248.

JOHNSON, T., 1633 The herball, or general historie of plantes ... very much enlarged and amended.. London: A. Islip, J. Norton \& R. Whitakers. Pp [xxxvi], 1630, [48].

LAET, J. de, 1647 De gemmis et lapidibus libri duo, quibus praemittitur Theophrasti liber de lapidibus, graece et latine. Leiden: J. Maire. Pp 786.

LANG, K. N., 1708 Historia lapidum figuratorum Helvetiae. Lucerne: G. Hautt \& J. J. Halter. Pp 165.

LINNAEUS, C., 1753 Species plantarum. Stockholm: L. Salvius. 2 volumes.

LISTER, M., 1678 Historiae animalium Angliae tres tractatus, unus de araneis alter de cochleis tum terrestribus tum fluviatilibus, tertius de cochleis marinis. London: J. Martyn. Pp 250

LISTER, M., 1685-1692 Historiae conchyliorum. London: M. Lister.

L'OBEL, M. de, 1655 Stirpium illustrationes. London: J. Kirton. Pp 549.

MAGNOL, P. M., 1720 Novus caracter plantarum. Montpellier: H. Pech. Pp 340.

MARTÍ-ESCAYOL, M. A., 2001 Catalunya dins la xarxa científica de la il-lustració. John Polus Lecaan: medicina i botànica a Barcelona durant la Guerra de Successio. Manuscrits 19: 175-194.

MERRET, C., 1667 Pinax rerum naturalium britannicarum: continens vegetabilia, animalia et fossilia, in hac insula reperta inchoatus. London: C. Pulleyn. Pp 223.

MOUFET, T., 1634 Insectorum sive minimorum animalium theatrum. London: T. Cotes. Pp 326.

PARKINSON, J., 1629 Paradisi in sole, paradisus terrestris. London. H. Lownes \& R. Young. Pp 612. 
PARKINSON, J., 1640 Theatrum botanicum. London. T. Cotes. Pp 1755.

PETIVER, J. 1695 Musei petiveriani centuria prima rariora naturae continens: viz. animalia, fossilia, plantae, ex variis mundi plagis advecta ... . London: S. Smith \& B. Walford.

PETIVER, J., 1698 Musei petiveriani centuria secunda et tertia ... . London: S. Smith \& B. Walford.

PETIVER, J., 1699 Musei petiveriani centuria quarta et quinta ... . London: S. Smith \& B. Walford.

PETIVER, J., 1699 Musei petiveriani centuria sexta et septima .... [London].

PETIVER, J., 1700 Musei petiveriani centuria octava ... . London: Smith \& Bateman.

PETIVER, J., 1702 Gazophylacii naturae et artis decas prima, in qua animalia, fossilia, plantae omniaque rariora arte producta descripcionibus brevibus et iconibus illustrantur ... . London: C. Bateman.

PETIVER, J., [1702] Gazophylacii naturae et artis decas secunda ... . [London].

PETIVER, J., 1703 Musei petiveriani centuria nona et decima .... London: Smith \& Bateman.

PETIVER, J., 1704 Gazophylacii naturae et artis decas tertia ... . London: Smith \& Bateman.

PETIVER, J., [1704] Gazophylacii naturae et artis decas quarta ... . London. Smith \& Bateman.

PETIVER, J., [1704] Gazophylacii naturae et artis decas quinta ... . [London].

PETIVER, J., 1713 Aquatilium animalium amboinae \&c. icones \& nomina, London: C. Bateman. Pp 4.

PLUKENET, L., 1691-1692 Phytographia. London: the author. 4 volumes

PLUKENET, L. 1696. Almagestum botanicum sive phytographiae Pluc'netianae onomasticon methodo synthetica digestum exhibens stirpium exoticarum, rariorum, novarumque nomina, quae descriptionis locum supplere possunt. London: the author. Pp 402.

PLUKENET, L. 1700 Almagesti botanici mantissa plantarum novissime detectarum ultra millenarium numerum complectens. London: the author. Pp 191.

PLUMIER, C., 1705 Traité des fougères de l'Amerique. Paris: Imprimierie Royale. Pp 146.

POURRET, P. A., 1796 Noticia historica de la familia Salvador de Barcelona. Barcelona: Matheo Barceló. Pp 32.

POURRET, P. A. and COLMEIRO, M., 1844 Noticia histórica de la familia Salvador de Barcelona. Nueva edición corregida y adicionada. Barcelona: Imprenta Verdaguer. Pp 16.

RAY, J., 1690 Synopsis methodica stirpium britannicarum ... . London: S. Smith \& B. Walford. Pp 317; 2 plates.

RAY, J., 1693-1704 Historia plantarum generalis. London: S. Smith \& B. Walford. 3 volumes.

RAY, J., 1705 Methodus insectorum seu insecta in methodum aliqualem digesta. London: S. Smith \& B. Walford. Pp 16.

RAY, J., 1713 Synopsis methodica avium \& piscium. London: G. Innys. Pp 378.

SALVADOR i RIERA, J., 1972 Viatge d'Espanya i Portugal (1716-17). (Edited by R. Folch i Guillén.) Barcelona: Edicions 62. Pp 105.

SCHEUCHZER, J. J. 1708 Itinera alpina tria: in quibus incolae, animalia, plantae, montium altitudines barometricae, coeli \& soli temperies, aquae medicatae, mineralia, metalla, lapides figurati, aliaque fossilia. London: Henry Clements. Pp 151.

SIBBALD, R. 1684 Scotia illustrata sive prodromus historiae naturalis. Edinburgh: J. Kniblo, J. Solingen \& J. Colmar. 3 volumes..

SLOANE, H. 1696 Catalogus plantarum quae in insula Jamaica sponte proveniunt ... . London: D. Brown. Pp 232.

VOLTES, P., 1967 L'arxiduc Carles d’Àustria, rei dels catalans. Barcelona: Editorial Aedos. Pp 311.

Received 12 September 2005. Accepted 19 October 2006. 
APPENDIX. Original texts of Joan Salvador letters and other documents written in French or Latin.

Abbreviations used in subheadings:

BL-Sloane $=$ Sloane MSS, British Library, London .

$\mathrm{JL}=\mathrm{J}$. Lecaan

$\mathrm{JP}=\mathrm{J}$. Petiver

$\mathrm{JS}=\mathrm{J}$. Salvador

1. JS to JP, 24 December 1706 (NS): BL-Sloane 4064, f. 124.

Monsieur

Il y a deux mois que je suis de retour de la france et de l'Italie, ou j'ai resté deux ans, seulement pour la cognition de Plantes, et du temps que j'etois a Montpellier, j'ai eü l'honneur de parler avec $\mathbf{M}^{\mathrm{r}}$ Nisolle de votre science dans la Botanique, et aussi avec $\mathbf{M}^{\mathrm{r}}$ Tournefort a Paris avec les quels je suis intime amy et nous avons le commerce de Plantes; comme aussi avec $\mathbf{M}^{\mathrm{r}}$ Triumfetti, et $\mathbf{M}^{\mathrm{r}}$ Tilli. Je souhaitterais $\mathbf{M}^{\mathrm{r}}$. avoir avec vous le meme commerce, en vous offrant tout ce qui depend de moy, et vous faire part de nos belles Plantes de la Catalogne, des quelles je vous envoie celles que j'ai pu ramasser apres mon retour, mais l'année qui vient j'auraoi le soin d'en ramasser beaucoup d'autres. Je vous prie $\mathrm{M}^{\mathrm{r}}$ de avoir la bonte de me faire part aussi des plantes et autres curiosités que vous receves des Indes, comme des coquilles, des Papillons, et autres, a la cognition des quelles je suis fort passioné; si vous souhaitez de des petrifications, du sel de Cardone, des coquilles, des plantes marines, et des plantes seches, en un mot de tout ce que contient l'histoire naturelle, je vous en faire part, de celles que nous avons en Catalogne; je vous prie $\mathrm{M}^{\mathrm{r}}$ de m'honorer de vos commandemens, et de croire que je suis

$\mathrm{M}^{\mathrm{r}}$

Votre tres humble et tres obeissant serviteur

A Barcelone ce $24 X^{\text {bre }} 1706$

Jean Salvador Apot. de Barcelona

Si me fessez l'honneur de m'ecrire c'est l'adresse suivante

A Jean Salvador metre Apoticaire au

Carrer Ample

Barcelona

\section{JS to JP, 22 September 1708 (NS): BL-Sloane 4064, f. 176.}

Monsieur

A la fin du mois d'Aoust j'ai receu par les mains de $\mathbf{M}^{\mathrm{r}}$ Lecaan celebre medecin de votre nation les Plantes et les Papillons mais ils etoint un peu gatté a cause de l'humidite. Le livre de $\mathrm{M}^{\mathrm{r}}$ Scheuchzerus, votre Museum et le Gazophilacium naturae et artis sans les tables (que je vous prie de m'envoyer) et quatre autres Tables ou sont figurés differents Crustacei et Plantes desquelles je vous pourrais envoyer presque tout. Je vous envoie une boitte dans le quelle vous trouverait les plantes qui sont dans le Catalogue, quelque petrification et des Cochlea, qui se trouvent en Catalogne, j'espere par une autre occasion vous envoyer quelque autre chose qui vous faira plaisir, et j'aurois soin en voyagent par Catalogne de remasser quelque chose pour vous. Je vous serai obligé Mr si vous pouviez m'envoyer les drogues qui sont dans le Catalogue et quelques Petrifications d'Angleterre, qu' a decrites $\mathrm{M}^{\mathrm{r}}$ Lister et aussi continuer a me faire part des Plantes et des Papillons et d'autres choses, que vous avez dans votre Museum, et j'espere que vous augmanterez le mien de choses tres rares. Si vous recevez quelque drogue rare je vous prie aussi m'en faire part car je desire augmenter beaucoup mon droguier. Si vous me faites l'honneur de m'envoyer quelque chose ne trouvent Persone fidel pour me le rendre, vous pourrez l'adresser a Mr George Crove, Consul de votre Nation a Barcelona ou bien le mettre entre les mains de Madame la femme de $\mathbf{M}^{\mathrm{r}}$ Lecaan, la quelle acommodera entre les Balots qui doit envoier a son mari a cette ville. Je vous envoie une lettre de change de sis livres Sterlines pour acheter les livres qui sont dans le Catalogue et si vous en manquent ne laissez pas de les achetter qu'apres je vous rembourserai l'argent qu'aurez depasse; J'ai redit vos compliments a $\mathrm{M}^{\mathrm{r}}$ Nisolle et a $\mathrm{M}^{\mathrm{r}}$ Tornefort, et de croire que je suis avec attachement.

Tuus humillissimus et additissimus amicus et servus.

Barcelona ce $227^{\text {bre }} 1708$

Dr. Joannes Salvador Barcinonensis Pharmacopus 


\section{JS to JP, 8 November 1708 (NS): BL-Sloane 4064, f. 184.}

Monsieur

J'espere que vous aurez receü par les mains de $\mathrm{M}^{\mathrm{r}}$ Pelham Johnston Phisitian in $\mathrm{S}^{\mathrm{t}}$ John's Colledge de Cambridge, ó sinon par celles de $\mathrm{M}^{\mathrm{r}}$ William Neilson Phisician at $\mathrm{M}^{\mathrm{r}}$ James Neilson in Litle Cisel street near de Queen's Weighouse de London, une boitte dans laquelle il y avoit des Plantes et des Petrifications; et une lettre de change pour m'acheter les livres marqués dans le Catalogue, et aussi un Catalogue des drogues que je vous demandés, en je vous prie de vouloir m'en faire part des celles plus rares que vous aurez, et aussi des Plantes et des Papillons, etc.; par la première ocasion qui partira pour London je vous envoyerai quelques coquilles et autres choses, je vous prie de vouloir continuer ce commerce, et de croire que je suis

Mr.

Votre tres humble et tres obeissant serviteur

Barcelona ce $89^{\text {vre }} 1708$

Jean Salvador

\section{JS to JP, 6 January 1710 (NS): BL-Sloane 4064, f. 218.}

Monsieur

$\mathrm{J}$ 'apprens par la lettre que vous ecrivez a $\mathrm{M}^{\mathrm{r}}$ le docteur Lecaan, que vous m' avez fait une bonne collection des Plantes et d'autres choses, je vous suis bien obligé, et je vous prie de les envoyer par la première occasion avec une partie des drogues contenues dans le Catalogue et les Livres que je vous ai demande l'année passée; je vous prie aussi si vous

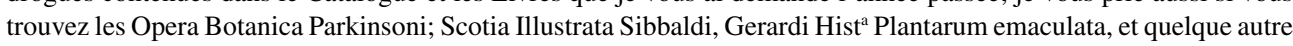
livre noveau de l'histoire naturelle, de me les envoyer, et me marquer le prix pour apres vous faire tenir l'argent; si vous recevez quelque chose, soit des Insectes, ou Poissons, Coquilles, Petrifications, Mineraux, Papillons, Drogues, $\& c$ je vous prie de m'en faire part, car j'espere que vous serais un gran augmentateur de mon Cabinet.

Dans peu de jours partira d'ici une flotte pour London, par la quelle je vous envoierai une boitte avec les Plantes contenues dans le Catalogue, et une bonne congelation du sel de Cardona; des graines je n'ai pas un grand nombre mais je vous envoyerai celles que j'aurai, je vous prie aussi de m'en faire part de celles que vous aurez, par une autre occasion je vous ecrire plus au long, je reste de tout mon coeur

Votre tres humble et tres obeissant serviteur et amy

Barcelone ce 16 janvier 1710

Dr. Jean Salvador apot.

\section{JS to JP, 26 February 1710 (NS): BL-Sloane 4064, f. 224.}

Alt. Dom. Jacob. Petiver

Credo, apud ad tuas manus jam pervenierunt duae alia littera unum Catalogo Plantarum hoc anno collectarum, et alio Catalogo quorundem Simplicium a me valde desiratorum, pro augmentum mei Musei. Nunc per navem dictam Hattley Frigatt cujus est Governator Capitan Thomas Young, pervenient Plantae contentae in Catalogo, et quaedam congelatione Salis Cardonae, et alia; hoc anno continuabo insiccatione aliquarum plantarum, et per occasione opportunam mittam. Quando accipies aliqua rariora, sit Testacea, Animalia, Plantae et similia naturalia [illeg.] aliquid mihi comunic[illeg.] et spero quod ex liberalitate tua meum Museum augmentabitur: desideratissima sunt mihi acta philosophica londinensium, et vellem habere omnia hujus centuria, et continuando singulo anno: non dum accepi libros in alliis Catalogis desideratis, et illos expecto per primam ocasione: vale et jube

Tuus in omnibus humillisimum

V. D $\mathrm{D}^{\mathrm{em}}$ Joannem Salvador Pharmacopeum

Barcinone 26 Februari 1710

\section{JS to JP, 12 February 1711 (NS): BL-Sloane 4064, f. 224.}

Monsieur

Dans le mois de dezembre passé j'ai receu l'honneur de la votre, dans la quelle j'apprens que vous avez receu les Plantes, Pierres \&c. que je vous avé envoié. Presentement par l'occasion de notre ami le $\mathrm{D}^{\mathrm{r}}$ Lecaan je vous envoie un Carton avec quelques Plantes, ne pouvant lui charger de porter autre chose a cause de son voyage par terre mais par la premiére occasion marine qui se presentara je vous envoyerai une boitte avec differens insectes que je garde pour vous (comme le dit $\mathrm{D}^{\mathrm{r}}$ Lecaan vous pourra dire) assez bien conservez. J'ai veü aussi dans la votre un Catalogue des Plantes desquelles vous en souhaittez quelques specimina, et de la semence pour planter dans le Jardin, j'espere ce printemps vous en faire la Collecte, encore que nous sommes bien malheureux dans ce pais a cause des enemis qui 
nous ont si reduits, ne pouvant voyager qu'une petite partie de Catalogne. J'espere ce mois d'Avril prochain passer au Port Mahon et a Majorque pour bien herboriser ce pais la et faire une bonne collection des Coquilles et Plantes, et alors je pourrai vous faire part de quelque belle chose encore que j'en attens d'un ami Apotiquaire qui demeure au dit Port Mahon [une] bone collection comme je l'apprens par ces dernieres lettres. C'est une persone qui a resté sept ans dans nostre Boutique. Les livres que vous dites il a long temps sont embarqués dans une flotte encore n'est point arrivée mais nous l'attendons de jour en jour; comme vous jamais m'avez ecrit quels sont les livres et son prix, je n'ai pú voir s'il fallait vous faire tenir beaucoup d'argent mais d'abord que vous m'en avertirez je tacherai de vous le faire tenir. Je vous ai aussi envoié differens listes de livres et si dans ceux que vous m'envoiez ni sont point ceux que seront contenu dans la presente je vous prie de me les envoier, comme aussi s'il en sort quelque autre et vous pourrez presentement l'adresser a Messieurs Schalet et Crove Consuls de la nation Angloise a Barcelone pour le faire tenir a moi, car de cette maniére viendront plus assurés et après m'envoiant le Compte je vous ferai tenir l'argent. Je vous envoie aussi un Catalogue de differentes choses semblable a celui que je vous ai deja envoié, si vous pouviez me les envoier ja vous serai bien obligé, et les mettrez tout dans des envelopes, et marquer dessus le nom. Si vous en avez d'autres non mentionées dans le present je vous en prie de m'en faire part, que j'espere comme vous ai deja ecrit vous m'augmentez de beaucoup mon Museum.

Je tacherai de remasser differentes especes des Crustacei et Fuci, Corallinae \&c que vous me demandez, encore que notre mer fort sterile, je vous les envoierai tout ensemble, et après vous les choisirez. Les coquilles terrestres et aquatiques que vous avez, je resterai fort obligé tant de ceux d'Angleterre comme d'ailleurs si vous pouvez m'en faire part, c'est une partie la quelle me plait beaucoup. Si vous sçavez quelque livre bon de cette histoire et des Animaux Volatiles, Aquatiques, Quadrupedes, \&c vous pourriez aussi me les envoier car je n'ai qu'Aldrovandus, Jonstonus, Bonani, Langius de Lapidibus figuratis Helvetiae. De nos amys de Montpellier il a long temps que je n'en sçai rien, j'espere qu'ils seront en parfaitte santé; l'autre jour me dit un Cirurgien Anglois qui venent de Genes qu'on lui avait dit que monsieur Tournefort eté mort mais comme je n'en ai point appris d'autres novelles je croye qu'il ne sera vrai. Si vous avez de petites branches de Caryophyllus aromaticus, Mirabolani, Cinnamomum et autres je vous prie de m'en faire part, je reste comme toujours de tout mon coeur.

Votre très humble et très obeissant serviteur et amy

Jean Salvador

Barcelone ce 12 fevrier 1711

\section{JS to JP, 30 July 1711 (NS): BL-Sloane 4065, f. 1.}

Port Mahon ce 30 juillet 1711

Monsieur

Par l'occasion de ces vaisseaux je posse de vous faire part dans celle ci de quelques plante que j'ai trouve dans cette Isle et particulierement du Myrto Cistus Pennaei Clus. que veritablement est une espece d'Ascyron le quel est rare en Minorque, mais je l'ai trouvé tres abondant a Majorque le quel j'ai nomme Ascyrum Balearicum frutescens, magno flore foliis minoribus, lucidis subsus verrucosis, du quel quand je serai a Barcelone je vous envoierai un grand exemplaire avec d'autres Plantes. J'espere de $\mathrm{M}^{\mathrm{r}}$ le docteur Stuard vous envoyera quelque chose quand il herborisera l'Isle dans le mois d'Avril et Mai car presentement la saison est trop seche, et le pais est trop sec et chaud. Je vous prie de m'envoier les livres que je vous avez demandé comme le tomus tertius Raii, le tome de $\mathbf{M}^{\mathrm{r}}$ Sloane, Scotia Illustrata, Acta Philosophica \&c et vous m'avertirez du frais, pour vous faire tenir de l'argent; les drogues demandées dans d'autres Catalogues et enfin tout ce que vous recevrez de nouveau tant des plantes comme des animaux et drogues. Je reste avec tout l'attachement possible

Monsieur

Votre tres humble serviteur

Jean Salvador Ap.

Par la flote qui arriva au mois d'avril j'ai receu les livres, et les plantes de quoi je vous remercie très humblement, mais vous ne m'avertisez point des prix car si vous avez deboursé de l'argent je vous le faire tenir.

8. JS to JL, 20 November 1711 (NS): BL-Sloane 3338 f. 27.

Je vous prie de saluer de ma part a $\mathrm{M}^{\mathrm{r}}$ Petiver et de lui dire que $\mathrm{M}^{\mathrm{r}}$ Squire a deja delivre la boitte marquée $\mathrm{P}$. a Tarragona $\&$ je luy ecrive de l'ouvrir \& il m'a dit qui y est le Tom. 3 Ray, 5 ou 6 tomes des Act. Phil. Lon., des plants seches \&c et d'abord que je les aurai ici a Barcelone je luy ecrirai un catalogue des livres qu'il m'envoit pour luy faire tenir le reste de l'argent, mais qu'il ne reste (ou vous) de m'envoir les autres livres que je luy ai demande, comme Lister Hist. Conchiliorum in Fol. Appendix ad Hist. Animal. Angliae solummodo \& alii Tractatus de Hist. Naturali apud Listeri quia Hist. Angliae jam habemus. Ray synopsis Stirp. Britanicar. Method. Insector. Ejusd. Park. Theatr. Botan. \& Paradysus Hist. Pl. Gerardi Emaculata. Sibbaldi Scotia illustrata \&c Laet de Lapidibus. Willouby Ornithologia. Lobel [illeg.] illustrat. a [illeg.] Museum [Regia Societat.] Tous livres imprime en Angleterre \& d'autres que vous jugerez 
qui me manqueraient [illeg.] et voir avec $\mathrm{M}^{\mathrm{r}}$ Hay s'il m'envoi quelque livre si y sera le Museum de Willouby. En tout cas de ne les pas envoier [illeg.] au dit $\mathrm{M}^{\mathrm{r}}$ Hay je vous prie de lui faire mes profons respects\& de lui dire que j'ay une grande boitte pour lui envoir mais nous attendons vaisseaux de la flotte qu'apporta le Roy en Italie, qui dovoint partir pour l'Angleterre particulierement le vaisseau Grafton qui primitivement etait Capitain My L. Forlis ou est embarqué $\mathrm{M}^{\mathrm{r}}$ [Tronet(?)] amy de $\mathrm{M}^{\mathrm{r}}$ Petiver \& est le vaisseau que j'ai retournai de Mahon. Tout [illeg.] \& j'embarquerai ditte caisse sur le dit vaisseau et encore il y aura une autre caisse adresse a vous ou vous trouverez les [informations] de Barcelone pour $\mathrm{M}^{\mathrm{r}}$ Hay \& beaucoup d'autres choses pour $\mathrm{M}^{\mathrm{r}}$ Rand au quel je vous prie de saluer tres humblement j'espere qu'il me fera part de quelque chose rare. Je vous remercie de la correspondence que vous m'avez procure de $\mathrm{M}^{\mathrm{r}}$ Boerhaave Professeur de Leyden au quel j'ay deja repondu a sa lettre\& je luy ai deja plante quelque [illeg.] \& les y envoirai pour la premiere [illeg.] dans des vases \& et luy ai fait une bonne [commodité] \& je lui ai demande d'autres plantes que j'espere m'envoira.

Barcelone Nov. 20.1711

Salvador

\section{JS to JP, 10 January 1712 (NS): BL-Sloane 4065, ff 13-14.}

Monsieur,

Il y a long temps que j'attend une bonne occasion pou vous envoier une grande boitte remplie de choses, mais comme elles sont si rares depuis qu'est parti Monsieur l'Amiral Noris il n'y a eü point d'autre occasion, et alors j'etois a Majorque, dernierement j'ai receu la boitte marquée $\mathrm{P}$, par les mains de $\mathrm{M}^{\mathrm{r}}$ Squire dans la quelle j'ai trouve Raii \&c vous trouverez a la fin de celle ci une liste des livres que j'ai receu de vous; mais j'attendes les autres que je vous ave demande particulierement le troisieme tome de l'histoire des plantes de $\mathrm{M}^{\mathrm{r}}$ Raii l'Histoire des plantes de la Jamaique de $\mathrm{M}^{\mathrm{r}}$ Sloane et autres que vous aurez eu voir avec les lettres que j'ai ecrites a notre amy $\mathrm{M}^{\mathrm{r}}$ le docteur Lecaan avec le quel je vous prie vouloir bien acheter et m'envoier les autres qui serait contenus dans autre Liste, ce que j'atten par la flotte qui viendra au printemps prochain comme aussi les Drogues, Pierres figurées, Coquilles, Mineraux, Terres, $\& c$ que j'ai eu l'honneur de vous demander dans les autres lettres. Je vous prie de vouloir en continuer touts les ans a m'envoier les Memoirs Curious \&c dans la boitte derniere j'ai trouve celles du mois de Janvier 1709 jusque au mois d'aoust 1709 me je trouve qu'en differents endroits il y manque quelque chose que je trouve y manquaient les nombrez de pages, je vous prie aussi de m'envoier le reste des Tables du Gazophilacium depuis Tab. 50 jusque aujourdui avec l'explication, comme aussi si vous avez imprimé quelque chose ou si quelque autre aient imprime quelqu'autre chose, je vous prie de m'excuser du retardement a vous envoier la ditte boitte, il serait bon que touttes les fois qui viendret quelque persone de votre connaissance de m'ecrire car alors je pourre plus commodement lui donner ce que j'aurois, car a la fois ils ne se vouloient charger des ces sortes de choses mais [illeg.] beaucoup des plantes, que ne viennent que par rejetons, si vous souhaitte que je vous en plante dans des caissesje le faire volontier. en faisant ce que je vous ai dit de m'ecrire par les personnes de votre connoissance qui viendront, et en attendent je reste de tout mon coeur Monsieur votre tres humble et tres obeissant Serviteur Jean Salvador Apoticaire de Bar

Liste des livres que vous m'avez envoiez

Morissoni Hist ${ }^{\mathrm{a}}$ plantar. 2 tom. in folio

Raii hist ${ }^{\text {a }}$ Plantar. 2 tom. in folio

Plukenetii Phytographia, Almagestum, mantissa Almagesti et [Analectum] Botanicum

Phytologia britanica

Collectanea chymica Leydensia

Itinera Alpina Scheuchzeri

Merret Pinax rerum Britannicarum

Catalogues des Livres que je souhaitte, et que j'ai ecrit a Mr le docteur Lecaan de m'envoier

Raii hist ${ }^{\mathrm{a}}$ Plantarum tomus tertius Solum modo 1705

Sloan de plantis Jamaicae in folio

Hist $^{\mathrm{a}}$ Conchiliorum Listeri in folio ejusdem Appendix ad hist ${ }^{\mathrm{a}}$ Animalium Angliae solum modo et alii tractatus hist ${ }^{\mathrm{a}}$ naturalis

Raii Synopsis Stirpium Britannicarum

ejusdem Methodus Insectorum 1705

Joannis Gerardi hist ${ }^{\mathrm{a}}$ Plantarum emaculata

Joannis de Laet de Lapidibus 
Sibbaldi Scotia illustrata in fol

Parkinsoni Theatrum botanicum et Paradisus

Acta Philosophica Londinensium

Lob. Illustrat. acurante ... Anglo

Museum Regia Societatis

Franci Willugbei Ornithologia edita Joanne Raio

Hortus Regius Blesensis [auctus] a d. Morisson

Charleton de differentis Animalium ... 1638

de Bry florilegium

Lob. Icones

Tabernemontani Icones

Moufetti Theatrum Insectorum

et aliis de hist naturali preter Aldrovandum et Jonstonum quorum opera possideo.

10. JS to JP, 26 January 1712 (NS): BL-Sloane 4065, f. 17.

Barcelone le 26 janvier 1712

Monsieur

Vous recevrez avec [illeg.]une caisse a votre adresse et marquée I. P.dans la quelle vous trouverez une autre boitte avec des insectes, les Plantes que j'ai aporté de Minorque, Pierres, Coquilles, une Squilla lata et autres choses, qu'il avoit long temps j'avois pour vous l'envoier, mais j'attendais quelque flotte, mais, n'ayant pas esperance d'enpartir j'ai voulu risquer avec cette occasion. Comme l'année passée les ennemis occuperet presque toute la Catalogne il n'est pas etoit possible d'herboriser, mais j'espere qu'on faire cette année une bonne campagne et nous aurons le pais libre, alors je tacherai de vous remasser des graines, plantes seches et autres, je ne sçai pas si vous aurez a mal que planterai dans des caisses quelques plantes rares, mais je souhetterai que quand viendra quelque un de vos amis de lui charcher de prendre ce que je lui donnerai et de m'ecrire parce que je puisse le connoitre. j'attends par la première flotte ce que je vous ai demandé dans les autres, je reste toujours

Monsieur

Votre tres humble serviteur et ami

Dr. Joan Salvador Apoth.

\section{JS to JP, 2 February 1712 (NS): BL-Sloane 4065, f. 20.}

Monsieur,

J'ai eu l'honneur de vous ecrire plusieurs fois que j'avois receu la boiette que $\mathrm{M}^{\mathrm{r}}$ Squire aporta marquée P. dans la quelle j'ai trouve Tomus primus et tom. 2 his $^{\text {ra }}$ plantar. Raii. je ne souhaitte qavoir que le tomus tertius car les autres il a long temps que je les avois mais n'obstant cela je vous prie de me les envoier avec les autres que je vous ai demande plusieurs fois, comme Sloan, Parkinson, Lister, etc. Je vous envoie par le navire Galere Marie Capitaine Daniel Hutchinson [Pritchard] la boitte qu'il avoit long temps gardez pour vous. Vous y trouverez une boitte avec plusieurs insectes, les Plantes que j'ai aporté de Minorca, Coquilles, pierres, une Squilla lata, etc. que j'espere arrivera tout bien conservé. Est a votre adresse et avec la marque I. P. Il y va embarqué un cirurgien du Port Mahon mon amy nomme $\mathrm{M}^{\mathrm{r}}$ Harvick. J'attends quelque chose par la première occasion comme les drogues, Coquilles, Livres, etc. Je reste de tout mon coeur

Monsieur

Votre tres humble serviteur

Jean Salvador

Bar $^{\text {ne }}$ ce 2 fevrier

$\underline{1712}$

\section{JP to JS, 15 July 1712 (NS): BL-Sloane 3340, ff 222v-223r.}

\section{$\mathrm{D}^{\mathrm{m}} \mathrm{Joh}^{\mathrm{s}}$ Salvador}

Pyxidem quam misisti per Duc ${ }^{\mathrm{m}}$ Hutchinson cum plantis quas collexeisti apud Portum Mahone recepi quae multo gratiore fuerent si non relictae fuissent illarum quas ad $\mathrm{D}^{\text {num }}$ Rand misisti ille qui nihil publicavit [sise] nec beneplacitus est illo quod ego facio. $\mathrm{D}^{\mathrm{r}}$ Sloan secretarius Regiae nostrae Societatis, cui obligatus [es] pro munere, quod (per meum rogatum) sibi misit Historiae Naturalis Insulae Jamaicae, librum tam multum desiderasti, potius expectavit recipisse Duplicata qua condonare potuisses, quam alteri data fuissent qui non est ejus amicus: [....] munus reditu pro Libro ejus, eum induxisset (quod ejus mente fuit) ite admisisse membrum Regiae Societatis nostra quod potestate ejus est 
inclinatissime una cum mea possest obtingeri, quia in hunc annuum sumus ambo de Consilio. Primo cogitavi publicare in nostris Actis Philosophicis ea qua misisti \& figuras delineare illorum qua nondum figurata fuere, sed prevenire Censuras $\mathrm{D}^{\mathrm{ni}}$ Rand relinquero sibi [mer] cui majus otio est.

Attamen per proximas naves mittam amplum reditum pro illis jam missis \& fortassis inter haec sunt aliqua qua nec $\mathrm{D}^{\text {us }}$ Rand, nec ullus alter praeter me possunt similia redire, \& in futuro semper [respiciem] qua mihi solo \& amicis [missoi] potius quam aliis similiore redibo.

Per ultimas misi varios libros quibus scripsisti, \& per proximas habebis plurimos reliquorum viz: Listeri Historiam Conchyliorum \& Appendicem, Gerard, Grew, Charleton, Parkinson, Ray, Willoughby, \&c. \& [ore te] in mandatis dare mihi pecuniam prioribus. [Inclusu] tibi [mito] Catalogum concharum Anglicarum \& fluviatilarum \& terrestriarum quas [illeg.] tibi misi, \& per proximas naves habebis marinas \& multa alia qua tibi jam seposus quibus videbis quam multum sum

voster servus qua humillissimus

J. P.

\section{JS to JP, 15 April 1712 (NS): BL-Sloane 4065, f. 34.}

Barcelone ce 15 Avril 1712

Monsieur

J'espere que vous aurez receu une caisse avec differents plantes des Isles Baleares, Coquilles, une Squilla lata \&c par le navire apellé la Galere Marie Capitaine Daniel Hutchinson, qu'il a quelque temps que partit de ce port, dans peu de jours j'irai a Montserrat et je tacherai de porter quelques plantes pour vous, et si le temps, et les ennemis le permettent j'espere aller aus Monts Pyrinees, et je vous promets de touttes les plantes, semences \&c. que je trouverai de vous faire part, j'attend quelque chose de vous par les premiers vaisseaux particulierement les livres que ja vous ai demandé dans mes precedentes. je reste de tout mon coeur

Monsieur

Votre tres humble et très

obeissant serviteur et amy

$\mathrm{S}^{\mathrm{r}}$ Jean Salvador Apotiquaire

\section{JS to JP, 22 August 1712 (NS): BL-Sloane 4065, f. 52.}

Monsieur

Ces jours passes j' ai receu par la voye de $\mathrm{M}^{\mathrm{r}}$ Quait une petite boitte avec quelques coquilles de quoi je vous remercie tres humblement, vous priant de nouveau a la continuacion de vouloir bien me faire part de vos belles choses; comme notre pays n'est trop abondant en varieté de choses je ne puis pas vous envoier tout ce que je pourrais mais enfin ce que je trouve je tache de vous en faire part, et comme je ne puis pas toujours estre a la campagne et rouler notre pais c'est une chose encore qui me prive de trouver quelque autre chose d'avantage, particulierement pour estre une partie occupé par les ennemis, mais je vous assure que j'ai bien de paine lors que je ne vous envoi tout ce que vous souhaitez et pour ces raisons vous m'excuserez et voudrez bien continuer a me faire part de tant de choses que tout les jours vous aportent differents $\mathrm{M}^{\mathrm{rs}}$ des Indes et ailleurs, mais ici moi tout seul faut que je le remasse. je reste en attendant quelque chose

Monsieur

Votre tres humble et tres obeissant serviteur

Barcelone ce 22 Aout 1712

Jean Salvador

\section{JS to H. Sloane, 22 August 1712 (NS): BL-Sloane 4065, f. 83.}

Monsieur

Le renom de votre tres excellents merite et curiosité dans la Botanique, et dans toute la connaissance de l'histoire naturelle, m'a fait il y a long tems desirer l'ocasion de vous feliciter la dessus, presentement Monsieur le docteur Lecaan m'a encouragé de me faire l'honneur de vous ecrire puis qu'il me dit que je tache de vous faire une bonne collection de touttes choses naturelles (me disant encore que vous me fettes present de votre livre le quel j'attens avec une grande impacience) je vous promets que je tacherai de vous satisfaire la dessus particulierement des choses de chez nous, et comme presentement je n'ai pas eu le temps de le faire seulement je vous envoi quelque chose que $\mathrm{Mr}$ le docteur Lecaan vous donnera, esperant aussi vous me fairez part de vos bonnes collections des choses des Indes que je crois vous en serais tout rempli. Je vous prie de pardonner la liberté que je prens et d'accepter en bonne part l'offre d'une sincere amitie et des me meilleurs services en le commerce de ces choses, avec l'assurance que vous 
me trouverez prest a vous envoyer toutce que vous souhaitterez de chez nous, vous me ferez beaucoup de plaisir et m'obligerez beaucoup d'estre toujours

Monsieur

Votre tres humble et tres obeissant serviteur

Barcelone ce 22 aoust 1712Jean Salvador

mon adresse est

Jean Salvador Apotiquaire au

carrer ample

Barcelona

\section{JP to JS, 14 October 1712 (NS): BL-Sloane 3340, ff 223r-225r}

Ad $D^{\mathrm{rm}}$ Joh $^{\text {nem }}$ Salvadore

Opportunitatem mittendi aliqua tibi ut promisi primam reditu illorum a te receptis restringere volui: plura fuissent, si abitus hujus Generosi $\mathrm{D}^{\text {ni }}$ Naper Chirurgi, tam subitus non fuisset. Attamen invenies circiter quadraginia specimina Plantarum Americanarum praecipue a Virginia reliqua ex Jamaica. Utinam reliqua earum specimina magis acurata fuissent, sed multa earum collecta sunt manibus rusticis inscitiisque quia sunt pauco aut nullo in partibus istis qui Rem Herbariam intelligunt multo minus delectantur collectione aut notitia earum: Istis jam dictis [ad]diunxi supra quinquaginta Cyperos Anglicanos, Cyperoides, Juncos \& Gramina Juncea, \& quamvis haec innumera sunt prope duplicata istorum quae missisti mihi a Porto Mahon (unde volumina duo nuper recepi ab altera manu \& plura quotide expecto) tamen non aegre fero tibi duplicata radices istis qua mihi mittis si rara sunt \& nondum in manibus alienis.

Et rebus ita transactio potes per unam quamque opportunitatem expectare talia specimina, \& ex Asia, Africa \& America qualia nullus, me excepte, potest tibi mittere, \& compensatione sit optandum in futuro quod non omittes ullas opportunitates procurandi collectiones \& Animalium, Vegetabilium \& Fossilium ex partibus [illeg.] utrarumque Indiarum quibus Hispani me[rcatur]as faciunt, praesertim Peruvianis \& Mexicanis ex quo ultimo loco spera [illeg.] us illustrere Hernandez \&c.

Interim quacumque partes vestra praebent valde grata erunt ut Squilla lata Rondeletii \& Cancer nuper mihi fuerunt. Olim tibi misi \& jam [reitero] Catalogu ex isto [auctore] Animalium crustaceorum qua videre gaudebo, \& tunc dicam an congruunt estis paucis qua littoribus nostris habemus quorum tibi nuper misi Catalogu

Jam impressurus sum Synopsim Avium \& Piscium mane scriptam $D^{\text {no }}$ Ray \& si per proximam opportunitatem mihi mittes catalogum amborum generum qua partes vestra [praebent] adjungera. [Nosco] Bellonium \& Rondeletium de [illeg.] bene tractavisse attamen fortasse istis potes addere quidquid novum.

Animalia ipsa praecipue minum facile mittes in Aqua Vita aut aliis Spiritibus, novarum dabo Figures \& addam tales observationes quas mihi mittes. Nam fidenter tibi affirmo quod nostra Regia Societas valde propensa est omne Hist. Naturalis partes promovere \& incitare omnes ejus Amatores. Inven[illeg.]es per inclusu quales libros tibi jam missi $\&$ per proximas naves addam quicumque petiveris, cum aliis qui jam in [prae ... ] sunt.

Est mihi in futuro (si tibi placet ut tam saepe a res audiam) singula mense colligere tibi aliqua Curiosa Natura [illeg.] vel Animalium, Vegetabilium aut Fossilium, \& praecipue per proxima oportunitatem recipies ampla Materia Medica collectionem, referentem istis tam maxime desiderasti vestro catalogo [ore] igitur a te cito \& officiter audire quod responsium erit a vestro amico amantissimo

Jacobo Petiver

Oct ${ }^{\text {ris }}: 14^{\mathrm{o}}: 1712$

\section{JS to JL, undated: BL-Sloane 4067, f. 134.}

Monsieur et cher amy [Lecaan]

Il a bien long temps, que je n'ai point receu de vos novelles ne sachant si vous etes en Anglaterre ou ailleurs. pendant le siege je vous ai ecrit deux fois adressant les Lettres a Majorque, pour aprez les envoier a Minorque, je ne scai si vous les aurez receues: vous aurez sceu notre horrible siege, mais graces au Seigneur notre maison a eté conservée, mon frere et moi avions resté dedans la ville, mon Pere avec le reste de la famille etoient dehors touts se portaient bien et vous saluent tres humblement. On vient de m'avertir de Port Mahon que pendant le siège le Winder Frigat debarqa quelque chose pour moi, j'espere qu'ily aura les livres et autres choses curieuses de Mr Rand, qu'il a long temps, que vous m'ecrivitez qu'on me les envoyerent par la premiere occasion, je verrai le compte de tout et je vous ferai [illeg.] votre argent, et aussi quelque chose de la reste de vos marchandises. Je vous prie de faire mes compliments a Mr Hay, et de me donner aussi de ses novelles, si vous pouvez tacher toujours de remasser quelque chose et obligeriez celui qu'est veritablement

Monsieur

Votre tres humble et tres obeissant 
serviteur et amy

Jean Salvador Apotiquaire

\section{JS to JP, 6 December 1714: BL-Sloane 4067, f. 186}

\section{Monsieur}

après tant des peines et des troubles, que nous avons soufert pendant un siege si long, j'ai receu une de vos lettres du 10 Aout 1713 avec un paquet des Livres, sçavoir Gazophyl. nat. tab. 100, Aquatil. Animal. Amboin., Raii English herbal., Synop. Avium et Piscium., Methodus Insector: et Musei Cent. j'ai vu aussi les livres ou son Catalogue, que vous me dittes sont embarquez dans le Winder Frigat. Après avoir ecrit a Alicant et a Maho pour sçavoir si ce vaisseau y etoient arrivé pendant notre siege, et s'il avoit debarqué quelque chose pour moi, j'ai sceu dernièrement, qu'il avoit debarqué beaucoup de choses pour Barcelone, et avec celles quelque chose pour moi, j'attends la reponse si seront les Livres de votre catalogue ou autres.

J'ai veu aussi Les prix de ces Livres Le valeur des quels je vous ferai venir par la première commodité, ou par $\mathbf{M}^{\mathrm{r}}$ Romani, ou de $\mathbf{M}^{\text {rs }}$ Schaler et Crove, et en meme temps je vous prie de m'ecrire si vous avez receu il a quatre ou cinq ans la lettre de change de six Livres Sterlins, que $\mathrm{M}^{\mathrm{rs}}$ Schaler et Crove vous devaient faire compter. J'espere ce printemps herboriser les Monts Pyrenees et Montserrat, touttes les plantes rares que je trouverai, je tacherai d'en secher aussi pour vous particulierement de celles qui fait mention Myconus: Je comence a ranger un autre fois mon petit Cabinet, que j'avois tiré de la maison par creinte des Bombes, je mettre apart quelques unes pour vous. Je vous serai bien obligé si vous m'envoyez les drogues pour la cognition de la Materia Medica, et les Plantes rares. J'ai receu jusque au nombre de 50 tables de $\mathrm{M}^{\mathrm{r}}$. Rai English Herbal mais il y en manquent diz, a sçavoir $\mathrm{n}^{\mathrm{s}}$ 1. 2. 3. 4. 5. 6. 7 . 8. 9. 10. [je] vous serai bien obligé si vous pouviez me les envoier, et aussi m'avertir si vous continuerez a faire les autres. J'ai veu aussi les Icones et Nomina Animalium aquatilium Amboinae, je trouve cela fort beau et bien gravé, mais vous m'obligeriez beaucoup si de touttes les coquilles que vous pourrez, mentionées dans ce Catalogue, m'en achetter une bonne Collection, a sçavoir une ou deux de chaque espece, a la cognition des quelles je suis fort attaché. J'espere que vous me fairez cette grace, et aussi me reccollirez touttes les curieusités que viendront entre vos mains tant d'Animaux, Mineraux [illeg.] \&c et obligerez veritablement

Monsieur Votre tres humble et tres obeissant serviteur et amy

Barcelona ce 6 xbre

1714

Jean Salvador Apotiquaire de Bar ${ }^{\text {lone }}$ 


\title{
ARCHIVES OF NATURAL HISTORY
}

\author{
EDITORIAL BOARD \\ Honorary Editor: Dr E. CHARLES NELSON (editor@,shnh.org) \\ Associate Editor: Dr JOE CAIN \\ Associate Editor (Book reviews): Dr PETER BARNARD (books@shnh.org)
}

Publication of Archives of natural history is the main way in which the Society for the History of Natural History fulfils its objectives. The journal provides an avenue for the publication of papers and short notes in all those areas of interest to the Society, and each issue contains a section of book reviews.

Archives of natural history is published twice a year, in April and October. Both parts contain at least 192 pages.

All papers submitted must be original; papers that have been also submitted elsewhere or are mere translations from another language cannot be considered. All papers are subject to peer review before acceptance. Instructions to authors, providing detailed information about the preparation of papers, are available on the Society's web-site and from the Honorary Editor who can also advise authors about the suitability and format of papers. Papers must be submitted in typescript (two copies, double spaced throughout) to the Honorary Editor, but final edited copy will be requested on disc.

Subscriptions to Archives of natural history are welcomed from libraries and institutions. History by

Archives of natural history is typeset and published for The Society for the History of Natural

\author{
Science History Publications Ltd \\ 16 Rutherford Road \\ Cambridge, CB2 2HH.
}

\section{SOCIETY FOR THE HISTORY OF NATURAL HISTORY}

The Society, founded in 1936, is an international society of individual members who are interested in the history and bibliography of all disciplines within the biological and the earth sciences. This is taken to include botany, general biology, geology (including palaeontology) and zoology; the lives of naturalists, their publications, correspondence and collections; the institutions and societies to which they belonged; and bibliographic studies of rare books, manuscripts and illustrative material.

Membership is open to anyone interested in the objects of the Society. The principal benefit of membership is receipt of the international journal Archives of natural history. A Newsletter is issued three times a year. The Society also organizes evening meetings and conferences, visits to places of interest to members, and a biennial two or three day international conference. Members may also purchase backnumbers of the Society's publications at reduced rates.

The Society has representatives in Central Europe, Italy, Japan, North America, Scotland, South America and South Asia.

Current membership details may be obtained from the Society's website www.shnh.org and subscriptions can be paid by credit/debit cards.

Membership enquiries: please contact the Hon. Secretary secretary@shnh.org.

Back issues of Archives of natural history may be purchased: enquiries may be addressed to the Hon. Treasurer treasurer@shnh.org. 